\author{
UNIVERSIDADE DE SÃO PAULO \\ FACULDADE DE CIENCIAS FARMACEUTICAS \\ Curso de Hós-Graduação em Farmácia \\ Área de Análises Clínicas
}

\title{
MICOPLASMAS: ISOLAMENTO E IDENTIFICAÇÃO EM MATERIAL CERVICAL DE GESTANTES
}

REGINA AYR FLÓRIO DA CUNHA

\author{
Dissertação para obtenção do grau de \\ MESTRE \\ Orientador: \\ Prof. Dr ${ }^{\natural}$. SUEKO TAKIMOTO MASAOKA
}

São Paulo

1987 
Dedico este trabalho

a. vocês,

Celso e otilia, meus pais

pelo amor que me dedicaram, peto exemplo, a dedicação e

sobretudo pela presença em todos

os momentos de minha vida.

e que foram a base para minhas conquistas...

A Raquelzinha,

minha grande pequenina,

A você Mariangelo,

querida maria, pelo apoio, peio carinho e pela amizade de sempre. 


\section{AGRADECIMENTOS}

E quase impossivel agradecer a todos que cola boraram na elaboração deste trabalho. no entanto, deixamos aqui os mais sinceros agradecimentos:

- Proga ora. SUEKO TAKIMOTO MASAOKA, pela orientação segu. ra, apoio e amizade a mim dedicados.

- Profa Dra. KIOKO TAKEI, pela amizade, carinho, incentivo e sobretudo pela valiosa e direta colaboração no desenvol. vimento do presente trabalno.

- Prola Dra. SUMIE HOSHINO SHIMIZu, pola aolaboragãa rece tada na revisão do texto e pelos conselhos oportunos, que tanto contribuiram para meu desenvolvimento cientifico.

- Prof. Dr. IOARUIM ANTONIO ROSSINI, pela oportunidade na iniciação ao estudo dos micoplasmas.

- ä ELSA MASAE MAMizUKA, pela amizade, carinho e estímulo ao ingresso na carreira cientíjica.

- Prói. Or. PAllio suyoshi MINAMI, coordenador do curso de Pös-Graduaçāo, pelo apoio durante co realização deste tra balho.

- Prof. Dr. BRUNo STRUFALDi, Cheje do Departamento, pelo es tímulo e apoio às atividades de pesquisa.

- a MARIA DE FATIMA BORgEs PAVAN, pelas suas oportunas ob servações na revisão linguistica do texto. 
- à Equipe Mëdica do Serviço de obstetricia doHospital dos clinicas da universiciade de são Pacilo, sob a cheria do or. MARCELO ZUGAIE, e em especial:

- à Dra. MARILENA CURY e Dr. MUCZO DINIZ PONTES, pela a.co. líida, pelo eritusiasmo demonstrado na realização deste tra balho e por nos ter permitido colher amostras de suas pa cientes.

- Or. ROSALvo GUIDOLIN, Coordenador do Setor de Fracionamen to do Instituto Butantã, cuja ajuda valiosa contribuiu para conclusão da parte experimental.

- à ANA MARIA fERNANDES, colega e amiga de tantos anos, che be do Setor de Fermentações da "SQUIBB", por todo carinhoe amizade demonstrados e pelos reagentes cedidos.

- Proj. Dr. Ney SOARES DE ARAUJo, Vice-diretor da Faculda de Odontologia da Universidade de São Paulo, que permitiu a realização dos trabalhos fotográficos na sua unidade $e$ em particular ao or. JOSE CAMPOS, fotógrafo, pelos servi ços e pela atenção a mim dispensados.

- à MARIA IZUMI OTTA, pela amizade demonstrada e pela cola boração na parte experimental.

- à MOEMA RODRIGUES oOS SANTOS, bibliotecāria, pela boa von tade e eficiência na correção das referências bibliogrābicas.

- à SiluANiA M.P. NEVES, Cinebe do Biotério cia Faculadade de Ciências Farmacēuticas da universidade de são Paulo, pela atenção que sempre. nos dispensou.

- äs colegas yOSHIMI I. YAMAMOTO e KATIIA S.C. PRINAVERA, De lo carinho e estimulo.

- à IDALINA AFONSO, pela precisãs nos serviços datilogrági cos e pelo carinho e amizade a mim dispensados. 
- a silvia paschoAl, marlene b.de assis, ä zu e marRo, pela aimizäle e pelo apoic am todos as haras.

- e ainda ä MARIA INES CARDILLO, CHENY CHANG, LUIZ CLAUDIO SILVA, SONIA CARAMICO, NEUZA DA SILVA, VALENTINA PIGOZZI, RONALDO MILHIM e a todos deste Departamento que, direta ou indiretamente, colaboraram para a concretizaçäo deste tra balho. 


\section{INDICE}

Pìg.

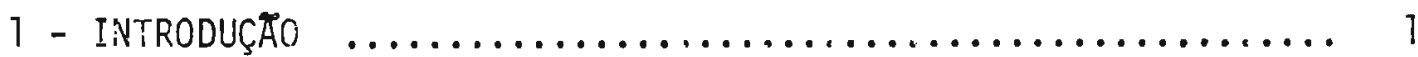

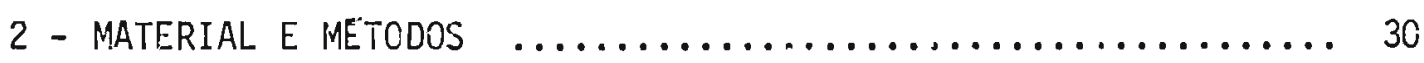

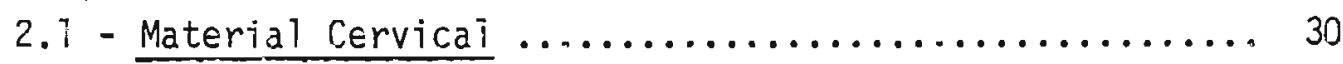

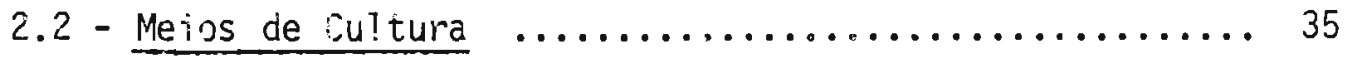

2.2.1 - Meic Tịquido de transporte - MLTr ......... 35

2.2.2 - Meio líquido utilizado para culti vo de Ureaplasma urealyticum -MLU ......... 36

2.2.3 - Meio liquido para cultivo de Mycoplasmas no trato jeniturinārio, que nidroiizam a arginina, tars como: Mycoplasma homenis e Mycoplasma fermentans : MLA ............. 38

2.2.4 - Meio 1íquido empregado na determinação da fermentação da glicose: MLG ............. 39

2.2.5 - Meio sōlido utiiizado no isolamerto de Ureaplasma wiealyticun e de outros micoplasmas genitais: MSM .................. 40

2.2.6 - Meio sōilido utịiıado pāra a reduçãc do

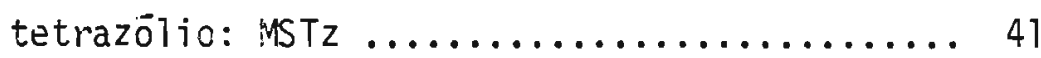

2.2.7 - Meio sōlido ut ịizaco para a determinação da atividâde da fosfatase: MSAF .......... 43

2.2.8 - Meio sölido utilizado pára a detecção da formação de filmes e "spots": MSFFS ........ 44

2.3 - Teste de sensibilicade à digitonina $\ldots \ldots \ldots \ldots \ldots . \ldots 45$

2.4 - Obtenção do anti-soro ...................... 49

2.4.1 - Imunização dos coelhos ................ 50

2.ட.2 - Titulação dos soros imunes obtidos ........ 5i

2.4.3 - Técnica de inibiçăo metäbōlica ........... 52 
2.5 - Identi ficação Sorciögica Jos Mi coplosimas

Isolados das Amostras Clinicas .................. 53

2.5.1 - Freparo do antígeno padrão na

forma solüvel ........................ 54

2.5.2 - Preparo dos antígenos solūveis, a partir dos micoplasmas isolados das amostras

clinnicas ............................. 55

2.5 .3 - Imunodi fusäo dupla de OUtCHTERLONY ......... 56

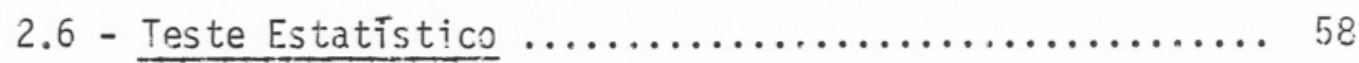

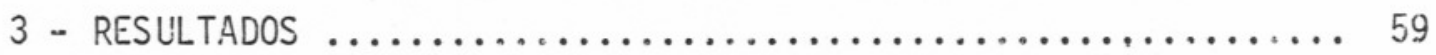

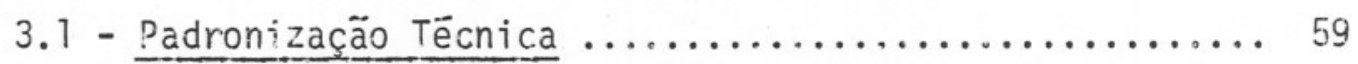

3.2 - Identificação das espëcies Ureaplasma urealyticum e Mycoplasma hominis nas amostras c!īnicas $\ldots . . \ldots \ldots 61$

3.3 - Isolamento do Ureaplasma urealyticum e do Mycoplasma hominis en amostras clinicas ............ 65

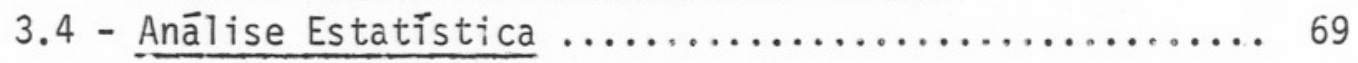

3.5 - Resultado das gestações das pacientes estudadas ..... 70

3.6 - Relação entre a presença de Trichomonas sp e

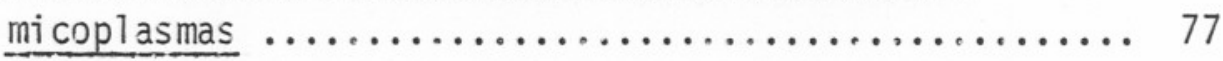

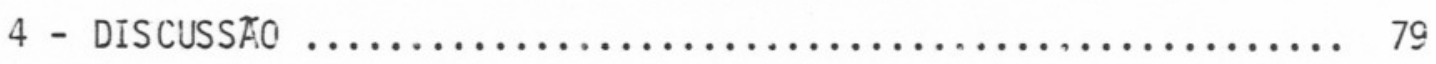

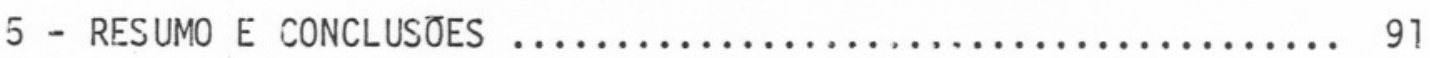

REFERENACIAS BIBLIOGRAFICAS $\ldots \ldots \ldots \ldots \ldots \ldots \ldots \ldots \ldots \ldots \ldots \ldots \ldots, 94$ 


\section{I - INTRODUCCÃO}

\section{HISTORICO}

O estudo dos micoplasmas teve início em 1882 com Louis Pasteur, o primeiro a reconhecer que a pleuropneumonia bovina, doença respiratória grave, era causada por um agente infeccioso específico, o qual não podia ser observado através da microscopia comum $e$ tambēm pouco cres cia nos meios nutricionais empregados usualmente em bacte riologia $33,59,108$.

Essa doença, que chegou a atingir rebanhos in teiros, assumiu grande importância econômica pela alta letalidade. Surgiı, de acordo com FCSTER ${ }^{38}$, na suiça e Alema nha por volta de 1713, e na Inglaterra em 1735. Em fins do sĕculo XvIII acabou disseminando-se por toda a França e Itä 1ia.

Da Inglaterra estencleu-se para a Austrália em 1858, através da importação de gado, e na mesma época, da Ho landa para a Africa do Sul, tendo posteriormente se disse minado para värias partes do mundo com exceção do oeste da Europa, India e Amërica do Norte. 
Nos Estados Unidos a doençä surgiu $\in m$ 1.843, ten do sido rapidamcrto erradicada, devido à implantação de me diàas governarnentais enērgicas $59,108,125$.

Na China, o primejro surto aconteceu em $1919 \mathrm{em}$ Shanghai, devico a um suprimento de leite de vaca contami nado vindo da Austrália; em 1920, na cidade de Hong Kong, foi tambēm evidenciada a presença da doença em rebanhos; procedendo a contaminação da mesma forte. Em 1932, o Regis tro de Saúde Municipal de Shanghai registrava que, naquele ano, 10,4\% do gado havia morrido em decorrência àa doen ça. $59,108,1.25$.

Dada a sua importância, värios pesquisadores vol taram suas atenções para a patologia e em 1898 NOCARD e ROUX obiiveram sucesso quanto ao crescimento do agente em meios artificiais, constituindo-se no primeiro grande passo ao es tudo do então denominado "Microbe de la Péripneumoniae"92.

Em 1910, BORDET seguido por BORREL, DUJARDIN -BEAÜMETZ, JEANTET e JOUAN ${ }^{8,9}$ descreveram minuciosamente 0 microrganismo em seus vārios estágios evolutivos, através do exame à fresco e com o auxílio do ultramicroscópio, evíden ciando seu intenso polimorfismo.

Suas dimensões diminutas permitiam sua filtra ção atravēs de filtros especiais que retinham bactérias e portanto sua capacidade de atravessar membranas filträveis os colocava entre os "vĩrus filträveis", não no senso estrito, uma vez que jä haviam conseguido sua multiplicação em meios artificiais $31,33,59,92,103$. 
Em 1923, BRTDE e DONATIEN ${ }^{1.2}$ cultivaram pela pri moira vez, am meio livrs de gelulas, o agente infercioso causado: da agalaxia, doença esta çue atingia sobretudo re banhos de carneiros e cabras. Da rnesma forma que o agente etiológico da pleuropneumonia bovina, este mostrou-se "fil trävel", e possuidor de caracteristicas morfológicas, cultul rais e biolögicas muito semelhantes, diferindo contudo do mesmo quanto à patogenicidade e às reações imunológicas ${ }^{12,94}$.

Enquanto a pleuropneumonia bovina, doença altamente contagiosa, caracterizava-se principalmente pela ex tensa consolidação, pleurisia e derrame subpleural afetan do normalmente um ou ambos os pulmões, a agalaxia era uma doença sistêmica que afetava machos e fêmeas igualmente, coin particular envolvimento das juntas, dos olhos e dos proces sos da lactação, podendo no caso de animais prenhes levar ao aborto de fetos mortos ou malformados $31,67,108$. A agala xia predomjnou na Europa, sobretudo nas regiões montanhosas da Itálià, França e Suiça, ocorrendo tambēm na Argélia.

Apesar de ter surgido una série de publicações referindo-se à morfologia e propriedades bioquímicas desses dois microrganismos $67,78,94, .130,134$, somente em 1934 , SCHOETENSACK fêz o terceiro relato, sobre o cultivo em meios artificiais, de un novo microrganismo com características semelhantes, desta vez isolado de cães com distúrbios res piratörios típicos da cinomose ${ }^{118}$.

Nos anos que se seguiram, microrganismos semelhantes a a agente da. pleuropneumoria bovina foran isoliados de outros animais sercio por essa razão denominados de PPLO ${ }^{33}$. 
EM 1935, KLIENEBERGER ${ }^{69}$, estudando culturas cio Streptobacielus moniliformes, habitante natural da rasofa ringe de ratos, julgou ter isolado um novo "pleuro-preuro nia-like organisms", denominando-o $I_{1}$. Inicialmente corside rou-o un simbionte do streptobacillus moniliformes, no que foi apoiado por DIENES ${ }^{25}$. Todavia, a continuidade dos estu dos sobre $I_{1}$, veio esclarecex que o mesmo não era um PPLO e sim una variante do bacilo, uma forma L. 24,26,68.

Na sequência de isolamentos e cultivos de novos elementos do grupo PPLO, una contribuição muito importante foi dada em 1936, quanäo LAIDLAW e ELFORD ${ }^{76}$ puderam caracterizar um grupo novo de microrganismos "filträveis", isola dos da água de esgotos de distritos londrinos. Esses assemelhavam-se muito aos membros do grupo PPLO, mas diferiam âqueles isolados anteriomento pela capacidado de crescer em meios de cultura sem soro, e por não serem patogênicos para os animais, sendo considerados cepas saprófitas dentro do grupo 33,108 .

\section{Posteriormente seguiram-se outros isolamentos} de microrganismos do grupo PPLO; de animais, do solo, de ma terial orgânico em decomposição, etc., até que em 1937, DIENES e EDSALI registraram o primeiro caso humano ${ }^{25}$. Esta cepa foi obtida em cultura pura, a partir da glândula de Bartolin sü purada, de um paciente que trabalhava no laboratório e cu jo contacto frequente com ratos servia como possível expli cação para o achado. Esta cepa perdeu sua viabilidade antes de ser identificada biolögica e sorologicamente. Contudo, em 1940, o próprio DIENES relatava o culzivo de PPIO do trato 
genital feminino ${ }^{23}$, sugerindo que, de acurdo com os novos conhecimentus, os loblantentos anteriores não possuram qual quer relação com o contacto com ratos ou outros animais. Quanto à patogenicidade nada ficou constatado, muito embora algumas evidências do primeiro isolamento assim a sugerissem.

A partir da descoberta de DIENES le EDSALI, hou ve um grande numero de registros sobre o frequente isolamen to de PPLO no homem, especialmente do trato urogenital, oro faringe e ocasionalmente de outras partes do corpo. A majo ria contudo não foi caracterizada antigenicamente ou preservada para uma futura anälise, o que impossibilitava fá. zer uma correlação entre as vārias cepas.

Em fins da dêcada de 30 e início de 1940 ficou evidenciado que um grande número de pneumonias não eram de origem bacteriana, sendo denominadas de "Pneumonias Atípi cas Primārias" (PAP) 59 .

Pelo fato dos agentes dessas pneumonias não se rem conhecidos, as PAPs foram clinicamente descritas como uma sinärome. Em 1943, notou-se que muitos pacientes acome tidos com a PAP, apresentavam crioáglutininas no soro, durante o curso da doença, cuja etiologia era cistinta das demais.

Em 1944, EATON evidenciou o agente através da. inoculação em ovos embrionados de galinha, do filtrado de escarro de pacientes com pneumonia ${ }^{59}$. o microrganismo pre viamente denominado "agente de Eaton" foi considerado um 
virus, atë que em 1962, CHANOCK et al. conseguiram seu cul Livo eñ meios artificiais caracterizando-o como um pPto. agente etiológico da doençá humana.17. Em 1963, Mýcoplasma pneumoniae foi o nome proposto pelo pröprio CHANOCK e cols., para denominar o agente da pAP ${ }^{16}$.

Posteriormente, vários outxos membros do grupo PPLO foram descobertos e caracterizados, principalmente os associados com o trato urogenital tanto masculino como fe minino, e a partir dai os esforços foram concentrados com a finalidade de definir sua real importância nas diferentes patologias humanas.

\section{TAZXONOMIA}

A nomenclatura dos microrganismos do chamado "grupo da pleuropneumonia" foi sempre bastante confusa. A vaiidade dàs publicações e a legitimidade dos värios nomes atribuídos aos membros desse grupo foram sempre questiona das.

o primeiro microrganismo descrito desse grupo, - agente da pleuropneumonia bovina, recebeu vārias denomi-nações. A primeira foi: Asterococcus mycoides, nome este atri buído por BORREL e col. em 1910, após seus estudos sobre a norfologia do microrganismo. Esses autores observaran que dentre as vārias formas sob a qual "le microbe" se apresen 
tava, as formações asteroidais erali cacacteristicis. A de

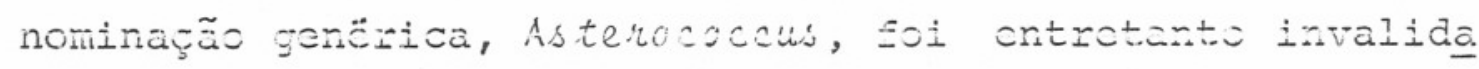
c.a, por ter sido atribuida anteriormente, 1908, a um gêne ro de algas ${ }^{110}$ sendo aceito apenas o termo múcoides.

Coccobacillus mycoides péripneumoniae foi à se gunda denominação do microrganismo, dada por MARTZINOVSKI, em $1911^{85}$, que ao publicar os resul.tados de suas pesquisas sobre a morfologia do agente evidenciou a predominância de formas cocobacilares sobre as asteroidais descritas anteriormente. o termo genérico coccobacillus jā havia sido atribuido en 1888 a um outro microrganismo de característi cas diferentes, e este, portanto, tambëm foi ilegitimado ${ }^{59}$.

Em 1923, F'ROSCH (citado em 93, propôs o termo Micromyces péripneumoniae bovis contagiosae, que foi também invalidado porque o termo genérico Micromyces já tinha si do empregado para denominar um grupo de fungos.

NOWAK, em 1929, fez uma revisão na literatura, quanto aos nomes que haviam sido usados. Não discutiu a no menclatura, mas descrevendo o microrganismo em estudo, pro pôs um novo termo enfatizando: "Ie terme My'coplasma pēripneumoniae semble répondre le mieux à la nature et à la morphologie du microbe"93. o epíteto pēripneumoniae foi invalidado, sendo substituido por mycoides, o qual tinha prioridade sobre os demais.

O termo genërico Mycoplasma (myces=fungo; plas malformado ou moldado, uma forma, *forma de fungo), foi acei. to publicamente embora es publicações subsequentes não o t.j. 
vessem adotado.

Em 1931, WROBLEWSKI ${ }^{134}$, estudando as razãoz pe las quais os autores anteriores haviam at:ibuido as cienomi nações, rão concordou com as já existentes e introduziu o termo Asteromyces pēripneumoniae bovis. o nome da espēcie foi invalidado, porque o epiteto perripneumoniae bovis foi empregado no lugar do termo mycoides, o gual era prioritá ric.

o agente etiológico da agalaxia recebeu a deno Ininação Anulomyces agalaxie do próprio WROBLEWISKI no mes mo ano ${ }^{134}$. O termo genérico Anulomisces foi por ele propos to por ter observaco o que ele chamou de "anneaux du myceiium" (anéis miceliais). o epíteto específico agalaxiae foi subs tituído por agalatial. A denominação foi aceita e assim os microrganismos causadores da pleuropneumonia bovina e da agalaxia foram colocacos em gêneros diferentes.

TURNER ${ }^{130}$, em 1935, discutinao a posição sistê mätica do microrganismo e sua nomenclatura, descartou todos os nomes genēricos atribuídos anteriormente, inclusive o tex mo Anulomyces, propondo o termo genérico Borrelomyces para "perpetuate the name of Borrel" (o primeiro a descrever mor fologicamente o microrganismo).

Denominou as òuas espécies de: Borrelomyces pēripneumoniae para o agente da pleuropneumonia bovina e. Borrelomyces agalactial para o agente etiológico da agala xì.a.

o epiteto përipneumoniae foi descartado por ra 
zões jä citadas anteriormente e o termo Borhcocmuces foi ilegitimado por ser a liltimo sinōnime dentre outros nomes genéricos, considerando-se que o termo Mycoplasma jä possuía prioridade sobre os demais.

Em 1941, SABIN ${ }^{108}$ propôs uma taxonomia e nomen clatura para os microrganismos do grupo PPLO, ignorando no mes e classificações previamente usadas. Todavia, foram tam bëm invalidadas devicio a ordem de prioridade de termos an teriormente atribuídos.

Em 1955, FREUNDT ${ }^{42}$ estabeleceu a primeira clas síficação dos microrganismos do grupo PPLO, baseado em suas propriedades gerais que foram assim sumarizadas:

- Crescimento em meios livres de céiulas. Necessidades nutricionais idênticas para a maioria das espécies.

- Peculiar modo de reprodução caracterizado pela ramificação de fi lamentos e divisão dos mesmos em corpos cocóides elementares.

- Pleomorfismo marcante.

- No meio sōlido, aparência característica de colōnias diminutas.

- "Filtrabilidade" das menores unidades reprodutivas.

- Polica afinidade aos corantes bacterianos.

- Alta resistência à penicilina e ao sulfatiazol.

Com base nessas características, com exceção da cepa saprófita M. Laidlcwii, cujas necessidades nutricionais eram diferentes dos demais, a classificação proposta por FREUND fCi: 
Ordern: Mycoplasmatales

Gēnero: Mycopíasima, ivoinak 1529

Espécie 1. M. mycoides (Borrei et al 1910)

Sub-espécie 1. M. mycoides var. mycoides

Sub-espēcie 2. M. mycoides var. capri

Espécie 2. M. bovigenitalium

Espēcie 3. M. agalactiae (Wrob lewski, 193!)

Um total de 14 espécies foram portanto determi nadas.

No mesmo ano, EDWARD ${ }^{32}$ sugeriu a seguinte nomen clatura e classificações básicas para os microrganismos do grupo PPLO:

Ordem: Mollicutales (Edward, 1954)

Família: Mycoplasmataceae fam. nov.

Gênero: Mycaplasma, Nowak 1929

Espēcie-tipo: Mycoplasma mycoides

o termo Mollicutales, introduzido por EDWARD ${ }^{35}$, baseava-se na plasticidade dos microrganismos, e o termo Mycoplasmatales, atribuidos por FREUNDT, derivava do nome da Eamilia, e apesar de seguir as regras de nomenclatura, era $\circ$ menos indicado pois sugeria uma rel.ação com fungos.

As duas denominações foram estudadas $\in c$ termo Mycoplasmatales foi considerado como taxonomicamente corre to.

Em 1967, EDWAFD e FREUNDT ${ }^{36}$ propuseram o termo Mollicutes (mollis=flexível, mole e cutis=pele), a fim de denominar una nova classe dentro da ordem Mycoplasmatales. 
Este termo foi aceilo pelo Subcomitè de Iáxonomia dos Myco plasmatales ${ }^{123}$, pcis fazta rofonancia à ausência de parede celular e à plasticidade da membrana desses microrganismos, caracteristicas fundamentais do grupo PRLO.

Reforçando a criação de uma nova classe, o estü do do comportamento bioquímico desses microrganismos revelou que a maioria necessitava de esteróis para o crescimen to. Estas características aproximavam os micoplasmas dos protozoários, sendo destes distinguidos pelá estrutura ce lular procariötica.

Em 1970, EDWARD e FREUNDT estabeleceram um no vo gênero, Acholeplasma, e foi criada uma nova família ${ }^{48}$, Acholeplasmataceae, dentro da ordem Mycoplasmatales.

Faziam parte do novo gānero os microrganismos do grupo PPLO que não necessitavam de esteróis para o cres cimento. O termo Acholeplasma ( $A=$ não; chole = demonstra relação com a bile; plasma = forma) indica portanto que 0 co lesterol, um dos constituintes da bile, não é requerido pạ ra o crescimento. A espécie A. laidlawii ficou sendo a es pécie-tipo do gênero ${ }^{34}$.

Emi 1972, o Comitê Internacional de Sistemātica Sacteriana(ICSB), juntamente com o subcomitê de Taxononia dos Mycoplasmatales, estabeleceram como padrões minimos à inclusão de novas espécies na ordem Mycoplasmatales: falta de parede celular, aparência colonial. típica, filtrabilida. de através de membranas filtrantes de $450 \mathrm{~nm}$ de diāmetro de poro, $\epsilon$ ausēncia de reversão à forma bacteriana sob condi 
Ções apropriadas. A classificaşão em Famíila, dependeria da determinação das exigëncias de extcréts para o desenvolvi mento, ficando a identificação das dijerentes espëcies bạ seada nas caracteristicas culturais, bioquímicas e antigê nicas 62 .

SHEPARD, em 1974, criou o gênero Ureaplasma (urea= urëia; plasma = forma), o qual compreendia micoplasma que requeriam uréia para o seu crescimento. Ureaplasma urealyticum foi a espécie considerada a espécie-tipo do gênero ${ }^{115}$.

Em 1973, SAGLIO e seus colaboradores, estudando um grupo de microrganismos que apresentavam forma helicoidal e motilidade rotacional, além de uma série de caractê rísticas pertencentes à classe Mollicutes, estabelecerara um novo gênero: Spiroplasma (spira = espiral; plasma = forma). Spiroplasma citri passou a ser a espécie-tipo do novo gêne ro 109 .

Este gênero foi incluído na família Spiroplasmataceae cujo nome foi sugericio por SKRIPAL em 1974, sendo todavia vạ lidado somente em $1983^{119}$.

Em 1979, forar. estabelecicios os padrões minimos para a descrição de novas espécies da classe Mollicutes ${ }^{61}$.

Foram ainda reconhecidos como pertencentes a es sa classe, os gêneros Anaeroplasma ${ }^{105}$ e Thermoplasma ${ }^{22}$.

o gênero Anaeroplasma, criado por Robinson e cols. em 1975, é constituído por micoplasmas araeróbios, tencio como espécie-tipo Anceroplasma abactoclasticun ${ }^{105}$. o gêne 
ro Theruoplasma, ouja espëcie-tipo EThêrmoplasina acidophilum ${ }^{22}$, foi axiado por DARIANT om io70, a compreende microrganj. mos que se desenvolvem bem a altas temperaturas. Esses dois gêneros, devido a algumas de suas características incomuns, näo estão bem definicos taxonomicamente.

o termo "micoplasma" é comumente usado para de notar qualquer espécie inciuída na classe Mollicutes, con tudo as denominações: acholeplasma, ureaplasma, espiroplas ma e anaeroplasma, são utilizados quando a referēncia é fei ta especificamente aos membros dos gêneros correspondentes ${ }^{100}$.

De acordo com o Bergey's Manual of Systematic Bacteriology de 1984,102 a posição taxonômica atual dos mi coplasmas è a seguinte:

DIVISAO: Tenericutes div. nov.

CLASSE I: Mollicutes (EDWARD \& FREUNDT, 1967)

ORDEM I : $\quad$ Mycoplasmatales (FREUNDT, 1955)

FAMTLIA I: Mycoplasmataceae (FREUNDT, 1955)

Gênero I. Mycoplasma (NOWAK, 1929) 9 $^{3}$

Espēcie-Tipo. Mycoplasma mycoicies (BORREL; DUJARDIN-BEAUMETZ;

JE.ANTET; JOLAN, 1910)

Gēnero II. Uireaplasma (SHEPARD; LUNCEFORD; FORD; PURCELL;

TAYLOR-ROBINSON; RAZIN; BLACK, 1974)

Espēcie-Tipo. Ureaplasma urealyticum (SHEPARD, 1974)

FAMILTA II. Acholeplasmataceae (EDWARD \& FREUNDT, 1970) 
Gēnero. I. Ácholeplasma (EDWARD \& FREUNDT, 1970)

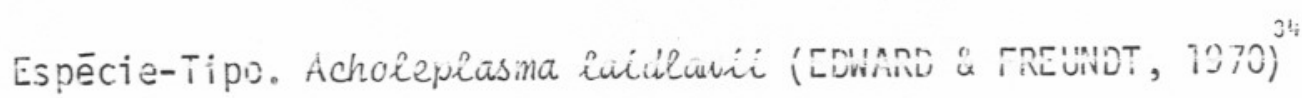

EAMILIA ITI; Spiroplasmataceae (SKRIPAL, 1983)

Gênero I. Spiroplasma (SAGLIO et a1., 1973)

Espëcie-Tipo. Spiroplasma citri (SAGLĩo et al., 1973)

Gêneros de Posição Taxonômica Incerta:

Gēnero: $\quad$ Anaeroplasma(ROBINSCN; ALLISON; HARTMAN, 1975)

Espēcie-Tipo. A. abactoclasticum (ROBINSON et $\left.\mathrm{al}_{3,}\right)^{105}$

Gênero: Thermoplasma (DARLAND; BRACK; SAMSONOFF; CONTI, $1970)^{22}$

Espēcie-Tipc. Thermoplasma acidophilum(22)

\section{CARACTERISTICAS GERAIS}

\section{Morfofisiologia}

Desde os estidos realizados no início do sécụ lo por BORDET e BCRPEL sobre a morfologia dos micoplasmas, seu intenso polimorfismo ficou caracterizado. A forma cocöi de é a forma predominante em todas as culturas, podendo tain bém ser observadas, na maioria delas, células alongadas, 
fusiformes e filamentosas. E'ssas podem algumas vezes se râ mificar dando origem a verdadeiras estruturas miceiiais.os memircs das familias Mycoplasmataceae e Acholeplasmataceae são portanto descritos como pleomórficos, com a forma celu lar variando de cocóide à filamentosa ${ }^{8,9}$.

Emse tratando dos membros da familita Spiroplasmataceae, a morfologia helicoidal, entre outras caracteristicas, è um dos principais critērios que os diferencia dos demais.

Quanto ao tamanho desses microrganismos, podem ser considerados os menores procariotos que se auto-replicam, sendo de $300 \mathrm{~nm}$ o diâmetro da menor forma cocóide capaz de reprodução. Esta dá-se quase que essencialmente por fissão birāria onde a divisão citoplasmätica deve ser sincronizada com a replicação do genorna. Quando isto não acontece, a divisão do citoplasma pode estar retardada em relação à do genoma, originando a formação de filamentos multinucleares. Estas formas filamentosas podem atingir $100 \mu \mathrm{m}$ de comprimen to por $0,4 \mu \mathrm{m}$ de espessura enquanto que no caso dos espireo plasmas, as formas helicoidais apresentam de 03 a $12 \mu \mathrm{m}$ de comprimento por 0,1 a $0,2 \mu \mathrm{m}$ de espessura 47,100 .

A ausência total de parede ceiular e de seus precursores é a característica mais importante que os dis tingue de outros procariotos, sendo responsävel pela maioria das propriedades desse grupo incluindo sua morfologia típica e plasticidade, sua sensibilidade à lise por choque osmōtico, álcoois, solventeə orgânicos, detergentes, anticor po e complemento; sua "filtrabilicace" através de filcros com poros de $0,45 \mu \mathrm{m}$ de diâmetro; sua morfologia coloniai cạ 
racteristica de "ovo frito" e sua total resistēncià à peri cilina c outras substâncias antibacterianes que degradam ou inibem especificamente a sintese de peptideoglicana. Portan to a falta de parede celular constitui a base para a inclu são dos micoplasmas na classe Mollicutes ${ }^{101}$.

A cêlula dos micoplasmas possui um mínimo de or ganelas essenciais para seu crescimento e reprodução. Uma membrana citoplasmática de natureza lipoprotéica separa o citoplasma do meio em que se encontra; ribossomos congregram as proteínas celujares e uma dupla fita de DNA forne ce informações para a sintese protéica 100,102 .

A relação guanina-citosina $(G+C)$, contida no DNA, é extremamente baixa (23 a $30 \mathrm{~mol} \%$ ), na maioria das espécies $^{100}$. A determinação do conteúdo G+C do DNA, tornou-se quase que obrigatória na descrição das vārias espécies de micoplasmas 47 .

o tamanho do genoma dos microrganismos pertencentes aos gêneros Mycoplasma e Ureaplasma,ē o menor regis trado entre os procariotos, refletindo sua limitada capaci dade biossintëtica 47,100 .

Frequentemente são imóveis, contudo algumas es pécies apresentam motilidade por deslizamento sobre super fícies lisas, deviajo provavelmente a organelas especiais cons tj.tuídas por proteínas conträteis. Outras espēcies, como as do gênero spiroplasma que ocorrem como filamentos helicoidais, possuem motilidacie rotacional, flexional e transla cional 47,102 . 


\section{Morfologia colonial}

De um modo geral, cs micoplasmas crescem em meio sólido originando pequenas colônias(menores que lnm de diâa metro), com aparência típica de "ovo frito", caracterizadas por uma nódoa central, devido ao crescimento no interior do meio, circundado por uma zona periférica de crescimento su perficial.

Apesar da morfologia cclonial não ter papel sig nificante na classificação das espēcies, estas algumas vezes podem exibir relevantes diferenças na forma e tamanho da colônia, dependendo principalmente do meio de cultura. Um exemplo que pode ser dado é o do Ureaplasma urealyticum ou $T \simeq$ micoplasma $(T=$ tiny $=$ pequeno, diminuto), que apresenta co Iônias atípicas e diminutas com diämetro variando de 5 a $15 \mu$ m quando do seu cultivo em mejos convencionalmente utilizados para o crescimento de outros micoplasmas. Todavia, em pregando-se meios nutritivos específicos para o seu cresci mento, as colōnias apresentam-se maiores (com diâmetro va riando de 30 a $40 \mu \mathrm{m})$ e na forma típica dos demais micoplas $\operatorname{mas}^{115}$.

\section{Necessidades nutricionais e metabolismo}

Os meios de ciltura emoregados no cultivo e iso lamento dos micoplasmas são bastantes complexos, tendo como base o infuso de coraçãa, peptonas, extrato de levedura e soro 100 . 
o soro fornece, entre outjos elementos, o coles terol e certns esteróis: parecendo estar relacionados com a fiuidez da membrana, e cuja dependência nutricional é ca racteristica da grande maioria dos nicoplasmas, tendo como exceção os membros da família Acholeplasmataceae e certas espēcies do gênero Thermoplasma, que não os necessitam pạ ra o seu crescimento 30,47 .

O Infuso de coração compōe-se sobretudo de amino ácidos e peptonas; aiēm de cextrose e vários íons, utilizą dos no crescimento e metabolismo dos micoplasmas.

o emprego do extrato de levedura como fonte de fatores essenciais exögenos, embora ainda não bem definido, parece estar relacionado com seu alto conteúdo em áci dos nucléicos e seus precursores, e com seu elevado teor em magnēsio 55 .

Para algumas cepas porém, o extrato de leveauu ra produz um efeito inibitório 43,111 .

A utilização da urēia como fator essencial de crescimento para microrganismos do gênero Ureaplasma,é uma caracteristica única entre os Mollicutes. A hidrólise in tracelular dà urëia, pelos ureaplasmas, resulta em amônia e diöxido de carbono, os quais originam lum gradiente iônico eletroquímico produzindo $\operatorname{ATP} 47,100,115$.

A fermentação da glicose ou outro carboiarato. pode servir como fonte de energia para os micoplasmas que utilizam a via de EMBDEN-MEYERHOF-PARNAS para a äegradação do carboidrato com produção de ATP. 
Estass e outras vias para obtenção de energi.a são utilizadac porque todos os micoplasmas atä agora estudados, com exceção do Thermoplasma acidophilum, micoplasma de vi da livre, possuem un truncado sistema respiratório mediado por flavinas, o qual exclui a fosforização oxidativa como um mecanismo gerador de ATP.

No caso de micoplasmas que não se utilizam de carboidratos energeticamente, O ATP necessário pode ser ob tido através da degradação da arginina pela via arginina- dehidrolase ${ }^{3}$, ou ainda a partir da acetil coenzina A por meio de reaçc̃es catalizadas pela fosfato acetil transferase e pela acetato quinase 3,132 .

Embora a grande maioria das espécies de My coplasma seja metabolicamente glicose-positiva (ex. M. pneumoniae) ou arginina-positiva (ex. M. hominis), umas poucas espécies são capazes de metabolizar ambas (ex. M. bermentans), enquan to que outras espëcies não se utilizam de nenhuma das duas vias (u. urealyticum) 47 .

A familia Mycoplasmataceae caracteriza-se pela heterogeneidade no que se refere ao catabolj.smo glicose/ar ginina, contrastando com a Eamilia Acholeplasmatacrae, onde todas as espécies sö catabolizam a glicose ${ }^{47}$.

\section{Comportamento Bioguímico}

Alëm dos testes biccuímj.cos envolvidos no meta bolismo dos micoplasmas, considerados como ce importância 
primāria na caracterização taxonĉmica, um pequeno nümero üe testes adicionais 'aujëri puden ser ütej.s.

Entre outros, podemos citar a Eermentação de carboidratos, que não a glicose, a atividade da fosfatase, a prođução de filmes e "spots" em meio sólido contendo ge ma de ovo, a redução do tetrazólio em condições aeróbicas e anaeróbicas, e a atividade proteolitica ${ }^{61}$.

A maioria destas provas denota propriedades de várias espécies e embora auxilie na identificação das mesmas, é de valor Iimitado na caracterização definitiva ${ }^{47}$.

\section{Habitat}

Os micoplasmas estão amplamente distribuídos na natureza, podendo parasitar o homem, os animais, os artrópo des e as plantas. Apesar de sua ubiqtidade, estes microrga nismos demonstram um alto grau de especificidace hospedeira.

o habitat primário dos micoplasmas no hospedei ro arimal, é a superfície da membrana mucosa dos tratos res piratörio, gastrintestinal e geniturinärio, sistema nervoso central, canal alimentar, olhos, glândulas mamārias e arti culações em alguns animais 100 .

Nas plantias, os micoplasmas habitam o floema cau sando uma grande variedade de doenças, destruindo plantações e causando sërios problemas econömicos. 
A transmissão se dá provavelmente através de in seios, nos quais os micopiasmas se multiplicain na homolinn-fa e glānculas salivares.

Em todos os processos patolögicos de plantas e insetos foram isolados espiroplasmas. Contudo, não somente espiroplasmas, mas tambēm acholeplasmas e micop̣lasmas tēm sido encontrados como comensais de flores e superfícies de plartas.

Embora algumas espëcies façam parte da microillora, muitas espécies são patogênicas causando uma variedade de doenças ${ }^{100}$.

\section{PATOGENICIDADE E MECANISMO DAS DOENÇAS}

Apesar dos mecanismos que mantēm o equilíbrio da flora normal nao estarem bem definidos, vários fatores re lativos ao hospedeiro como: a idade, o sexo, a predisposição genētica, o estado nutricional, bem como fatores extrîn sicos como: ambientais, condições de exposição, etc., pare cem estar correlacionados, para a manutenção da higidez or gānica.

Essencialmente todos os micoplasmas são parasi tas, milto deles aderindo à membrana da célula hospedeira. Essa acierência parece ser frequentemente o primeiro passo na colonização e patogenicidade $55,111$. 
priedades invasivas, alëm de um alto grau de especificidade pelos órạãos e tecicos infectados.

As consequências da infecção micopläsmica, nos tecidos do hospedeiro, variam àe acordo com o microrganismo e com o sistema orgânico envolvidos. As alterações obser vadas podem ser decorrentes de distürbios na função celu lar especializada, e a mudanças histopatológicas.

Dentre as espécies que causam patologias podem ser salientadas algumas de interesse humano, as quais possuem a capacidade de se ligar às membranas da céluía hospe deira, como M. pneumoniae e ureaplasma urealyticum ${ }^{19}$.

No caso do M. pneumoniae a capacidade de aderên cia se deve sobretudo a organelas que regulam a citoadsorção. Apesar de ser um patógeno do trato respiratōrio, sua capacidade de aderir às células epiteliais respiratórias não é exclusiva, estendendo-se a eritrócitos, macrófagos, esper matozóides e frequentemente a superficies inertes.

As consequências do parasitismo sobre a super fície celular do hospedeiro podem ser ilustradas pelo $M$. pneumoniae. Este, ao aderir a alguns tipos de eritrócitos, provoca lise celular devido à liberação de peróxido. No cạ so da infecção ocorrer na superfície de células epiteliais ciliadas, trocas metabólicas ocorrem, acarretando diminuição na síntese de nacromolēculas, com alterações na utili zação de carboidratos e na oxigeração. Deste modo, hä uma alteração na função celuịar com pexcảa do movimento ciliar. 
do por uma modificação nuclear, pela vacuclização citoplas mática e pejo desarzanjo das junçōes intercelulares, tenāo como corsequência a destruição das células parasitadas ${ }^{19}$.

Urraplasma urealyticum, quando aderido à membra na celular do trato genital, pode comprometer a atividade ciliar do oviduto provavelmente atravês da produção de amô nia a partir da urëia. Sua capacidade de reduzir a motilidade do espermatozóide por aderência, alterando o processo de fertilização, tem sido discutida ${ }^{14,41}$.

Outros micoplasmas atuam sobre o hospedeiro de maneira diversa: Mycoplasma neurolyticum, por exemplo, atra vés de sua neurotoxina, altera de maneira seletiva a permeabilidade capilar das células endoteliais do cérebro, pro duzindo em ratos a clássica síndrome denominada "doença do giro"i9.

Outro fator importante no mecanismo das doenças micoplásmicas é a permuta de antígenos entre o microrganis mo e a membrana da célula hospedeira. Essa transferência se ria decorrente da ausência da parede celular que permite um contacto estreito entre as membranas do micoplasma e da cé lula do hospedeiro. Desta forma, a aquisição de antígenos do hospedeiro, por parte do microrganismo, pode auxiliar o parasita a evitar ou alterar a resposta imunológica do mes mo. Por outro İado, a aquisição de antígenos micoplásmicos pela nembrana do hospedeiro pode desencadear reações auto-imunes, muito comuns nas infecções micoplásmicas 100 . 
secções por micoplasmas, o presente trabalino ten enfoque mais direcionado à infecção humana do trato geniturinärio, sencio que cias doze espécies da classe Nollicutes encontra das no homem, quatro estão associadas com alterações do tra to geniturinärio: Mycoplasma hominus, Ureaplasma urealyticum, Mycoplasma fermentans e Mycoplasma genitalium.

Presume-se que a grande maioria das cepas isoladas do trato geniturinärio humano, referidas entre 1940 e 1950 como "Pleuro-Pneumoniae-Like-Organisms" (PPLO), fosse de fato Mycoplasma hominis. Isto porque Mycoplasma bermentans só é isolado muito raramento e os demais, Mycoplasma genitalium e Ureaplasma.urealyticum, não poderiam ter formado colônias possiveis de serem reconhecidas naqueles meios utilizados e naquelas condições de crescimento ${ }^{45}$.

A relação entre o isolamento desses microrganis mos e a sua etiologia nas doenças humanas e mais particular mente nas patologias do trato urogenital, vem sendo objeto de estudos desde $1937^{25}$.

A baixa frequência de isolamento do Mycoplasma fermentans dificulta o estuco de seu potencial como patáge no. Uma vez que Mycoplasma genitalium foi identificado só recentemente com a utilização de meios mais complexos, o pre sente estudo foi. portanto dirigido para as espécies çenitais primärias: Mycoplasma honinis e Ureaplasma urealyticum. 
ENVOLVIMENTO DO Mycoplasma hominis E DO lireaplasma lireainticum NAS ALTERAÇÖES CLINICAW DO TRATO GENITURTMSTIO

As altas taxas de colonização desses microrgạ nismos, no homem e na mulher em idade fértil, mesmo sem qual quer sintomatologia de doença, torna difícil estabelecer uma relação entre a sua real patogenicidade e sua presença nas secreções vaginais e uretrais ${ }^{7}$.

Todavia, värios são os trabalhos que atribuem a esses microrganismos a etiologia de uma série de patolo gias. o Ureaplasma urealúticum,em particular, è responsabi zado por $50 \%$ das uretrites não gonocöccicas $4,10,13,112,127$.

Constatou-se que a incidêncià de micoplasmas na mulher é maior do que no homem, considerando-se grupos similares. Na mulher, a colonização vaginal pelo H. hominis e pelo Ureaplasma urealyticum, è maior naquelas de nível sócio-econômico mais baixo, $\in$ ccm atividade sexual mais in tensa. Ambcs os agentes säo mais frequentemente isolados em mulheres de raça negra do que em mulheres cie raça branca ${ }^{1,88}$.

Por serem os Mollicutes comprovadamente respon sāveis por uma série de problemas de reprodução em alguns animais e por serem algumas espécies capazes de causar in fecçäo no homem, pressupöe-se que analogamente a coloniza ção humana tambēm possa contribuir para a infertilidade e perda fetal 122,126 .

o estudo, que inicialmente ciespertou c interesse 
pelos micoplasmas inas chamadas "falinas da reprodução huma na", foi apresontado en 1967 por vindDSIN e DRISCOLL ${ }^{74}$, que ve rificaram o crescimento d.a. cepa ఇ’-micoplasma (ureaplasma), no cörion, decídua e âmnion de uma paciente que abortara no segundo trimestre de gestação. Subsequentemente a este achâ do, urna série de trabalhos tem se referido ao envolvimento desses microrganismos en vārias alterações materno-fetais tais como: febre puerperal e pös-aborto $6,58,64,77,120,129$ abor tos espontâneos, natimortos, nascimento aje prematuros, nas cimento de malformados e com baixo peso para a idade gesta cional $15,18,27,28,29,37,57,63,72,73,98,106,124$

o mecanismo que associaria a infecção ureaplăs mica com casos de aborto espontâneo, malformação fetal,etc., é desconhecido. Constatou-se experimentalmente que além do efeitc citopatico sobre as cēlulas, a ureaplasma é capaz de induzix aberrações cromossômicas como: falhas e "quebras" cromossomais, tetraploidias, etc. A alta frequência de per fis cromossômicos anormais em tecidos fetais abortados e o encontro de ureaplasmas em vários desses tecidos, sugeje que meihores estudos devam ser cada vez mais intensificados nes se sentido 49,71 .

GNARPE \& FRIBERG, estudando os micoplasmas nas alteraçöes da reprodução, constataram a alta prevalência dos T-micoplasmas no trato genital de pacientes com infertili dade sem causas definidas. Estes microrgarismos foram erra dicados após tratamento com doxiciclina, tendo siclo observado un aumento considerävel nas taxas de gestação em grụ po de casais tratados 50 . 
No que se refere ainda ao seu envolvimento em casos de infertilidade inexplicajos, ss T-micoplasmas podem causar endometrites na mulher, devido à sua fixação às cēIulas endometriais, enquanto que no homem, esses microrganismos podem ser encontrados aderidos às células espermáti cas, permanecendo ainda obscuro o mecanismo pelo qual isto ocorre 53,54 .

Entre outras causas de infertilidade, a doença pélvica inflamatória, patologia de eíiologia multifatorial, tem no Mycoplasma hominis comprovadamente um de seus agentes etiolögicos 90 .

A presença de micoplasmas na placenta, causando corioamnionites, pode conduzir ao dano de suas mültiplas funções, principalmente no que se refere à proteção do fe to às adversidades físicas, à rejeição imunolögica, indican do portanto fortemente sua associação aos resultados anor mais da gestação 75,118 .

Ainda associados a esses ricrorganismos, podem ser citados casos de prostatites, com reações inflamatórias ascendentes àa uretra para a próstata $13,133$.

Pacientes com sintomas agudos de infecçãc do trạ to urinário tiveram micoplasmas como os únicos microrganis mos isolados do jato médio de urina, bem como da urina obtida através de punção suprapública, reforçando que estes po dem também estar associados aos casos de infecção urināria ${ }^{89}$.

Culturas puras de Mycoplasma hominis foram obtidas de pacientes com pielonefrite aguda, evidenciando c 
seu papel çe patógero primário nesta patologia, uma vez que testes sorologicos jü teritan esta conclusãol.28.

Finalmerte, tem sido atribuído aos micoplasmas, sobretudo ao Ureaplasma urealyticum, participação efetiva nos casos de Síndrome de Reiter ${ }^{70}$, bem como na produção de cálculos urinários ${ }^{51}$ e de outros estados mörbidos.

\section{OBJETIVO:}

O presente trabalho teve como finalidade precí pua, na primeira fase, padronizar meios de cultivo para $\circ$ isolamento a manutenção do Mycoplasma hominis e to lireaplasinia urealyticum, bem como provas bioquímicas e sorológicas pa ra a identificação dos mesmos. A introdução de algumas mo dificações possibilitaria a sua pesquisa na rotina laboratorial diagnóstíca, ainảa em nosso meio bastante limitada pelas dificuldades técnicas e de aquisição de alguns compo nentes esserciais de origem estrangeira.

o trabalho teve tambëm como objetivo, em segun da instância, a verificação das taxas de colonização de Mycoplasma hominis e de Ureaplasma urealyticum no ärvix de gestantes, uma vez que a literatura internacional traz uma. série de registros envolvendo os micoplasmas, sobretudo lize aplas ina urealyticum, em casos de repetidos abortos espontâneos, nas cimentos de prematuros, natimo:tos, além de várias outsas 
alterações materno-fetais. Devido ao fato do próprio estado gestactonal tomar as gestantes un grupo bastante suscepti vel às infecções microbiaras, devido às variações hormonais, de pH e do próprio epitélio encionetrial, a imp̣licação da co Ionização mi.copläsmica no cếrvix despertou interesse dada a importância de seu possível papel patogênico nas altera ções peri-gestacionais. 

2 - MATERIAL E METODOS

\section{1 - Material Cervical}

A amostra clínica utilizada foi o material cervical de gestantes pertencentes a uma classe de baixo nível sōcio-econômico, que acorreram ao ambulatório de obstetrícia do Hospital das Clínicas da Faculdade de Medicina da Universi dade de são paulo, a fim de terem acompanhamento clínion 픔 te o periodo gestacional.

Fizeram parte do grupo de estudo setenta e quatro ges tantes, đas quais trinta e sete possuíam histörico anterior de alterações gestacionais, tais como: abortos, natimortos, prematuros e malformados, que constituiram o grupo de ris co. As outras trinta e sete gestantes que não haviam apre sentado anteriormente qualquer problema gestacional fizeram parte do grupo controle.

Desse total de gestantes, sessenta e duas apresentą ram seguimento atë o teérmino da gestação, possibilitando as sim obter dados referentes ao prcduto conceptual.

Dentre as gestantes do grupo de risco, quinze apresen 
tavam alterações gestacionais ciinicamente definidas (onze com incompotëncia ístmo cervical, duas com ovārio policístico, uma com ütero bicórnico e uma com ūtero hipopläsico).

Antes da coletá do material clinico propriamente di to, o conteúdo vaginal era colhido com auxíio de solução fisiolögica estéril, naterial este utilizado para o exame a fresco.

O material cervical foi obtido com o auxillio de dois "swabs" alginatados neutros, de uma região denominada fun do de saco de Douglas. Um dos "swabs" foi colocado em meio de transporte MLTr, em banho de gelo, até seu processamen to e o outro foi utilizado para a feitura de lāminas para a bacterioscopia pelas colorações de Gram e de Giemsa.

0 processamento das amostras clínicas assim colhidas foi o seguinte:

\section{A parti.r do meio NIITr, três alíquotas de $0,1 \mathrm{mI}$ foram semeadas do seguinte modo:}

- A primeira alíquota de 0,lmL do meio de transporte foi se meada diretamente en meio sólicio MSM e incubada à 37.C por 24 horas em microaerofili.a. Observado o crescimento de co lônias de micoplasmas, blocos com crescimento foram corta dos e congelados no respectivo meio liquido (MLA ou MLU).

- A segunda alíquota de 0, l.mL foi colocado en neio MLU, o qual foi incubado a $379 \mathrm{C}$ em microaerofilia por 18 a 24 ho ras. Verificada a alteração do pH, pela mudançà de cor do 
meio de amarelo para róseo, 0 , inil do mesmo foi semeado em meio sólizo MEM, o quall foi incubado a 3790 par 24 hores om microaerofilia. A observação microscópica do mio söli.do MSM (com aumento de $100 x$ ) e a constatação de colōnias pequenas de coloraçäo marron dourado, caracterizava a presença de ureaplasma urealyticum. Pequenos blocos, com crescimento do rnicrorganismo, foram cortados e com eles, utilizando-se a tēcnica "pushing block"(que será descrita oportinamente), reạ lizavam-se as provas de sensibiiidade à digitonina, e as pro vas bioquímicas de fosfatase, da utilização da glicose, da reduçäo de tetrazólio em aerobiose e anaerobiose. A prova da formação de filmes e "spots" foí realizaảa da partir de $0,1 \mathrm{ml}$ do meio líquido $\underline{\mathrm{MLU}}$ em que havia crescimento.

- E finalmente foi inoculado em meio líquido MLA e incuba do à 379c em microaerofilia por 24 a 48 horas. A variação de $\mathrm{pH}$, pelo aparecimento de cor púroura, alëm da turvação do meio, denotavam crescimento de micoplasmas que se utili zavam de arginina como substrato.

A partir desse mejo líquido $\underline{M L A}$ foi semeado $0,1 \mathrm{~mL}$ pa ra outro tubo de meio ljquido de $\underline{\mathrm{M}} \mathrm{A}$ A e congelado(para manu tenção das cepas). Outra alíquota de $0,1 \mathrm{~mL}$ foi semeada $\in m$ meio sólido MSM e, após ı̇ncubação por 24-48 horas a 379̣ em microaerofilia, foi fej.ta a observação microscópica da pla ca de meio MSM a fin c̈e se observar a presença ou não de co Ionias tipo "ovo frito". Em caso positivo, pequenos blocos contendo essas colônias foram recortados e com eles reali zadas provas de sensibilidade à digitonina 1,5\% e as pro 
vas bicquímicas de utilização de giicosa, de redução do te trazoljo em aerobiose e anaerobiose, e da fosfatose. o tes te da formação de filmes e "spots" foi realizado a partir.r da semeadura de $0,1 \mathrm{~mL}$ do meio MIA com crescimento, em meio sōlido MiSPFS.

o esquema do processamento ë o que segue: 
ESQUEMA DO PROCESSAMENTO DA AVOSTRA OLÍNICA

MATERIAL CERVICAL

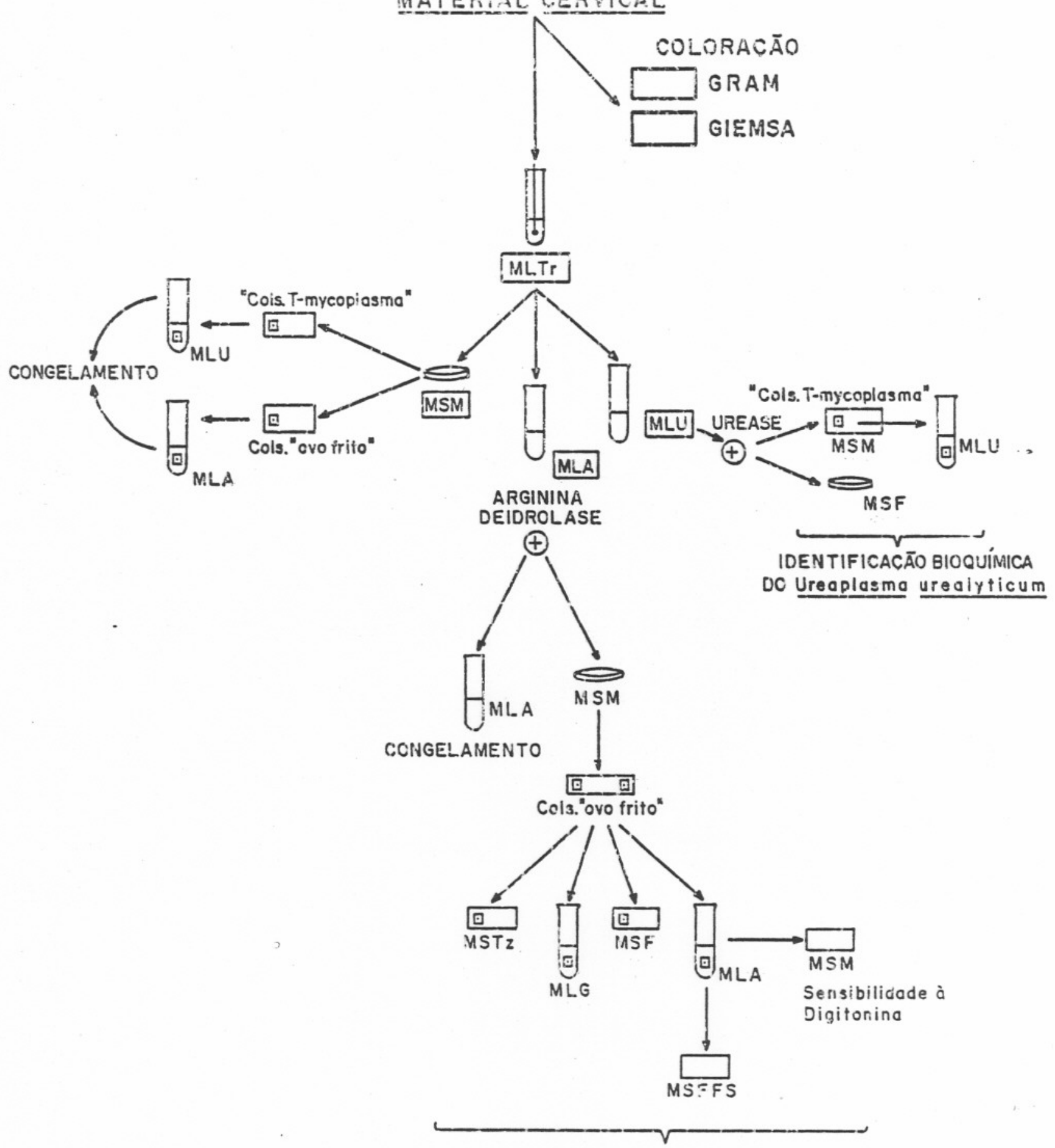

IDENTIFICAÇĀO PRESUNTIVA DOS NiycJplasmas sp 


\section{2 - MEIOS DF CUITURA}

No presente trabalio estĩo descritas todas as formu laçōes dos meios originais $\epsilon$ modificados, bem como as tëc ricas de semeadura e cultivo dos micoplasmas, a fim de for necer subsidios aos que pretendem desenvolver estudos so bre esses microrganismos.

Os meios utilizados para o crescimento, isolamento e caracterização dos microrganismos pertencentes à família Mycoplasmataccae, tiveram como base alguns meios litilizados por SHEPARD 113,114 e ALUCTTO ${ }^{2}$, aOs quais foram introduzidas algumas modificações a fim de adaptä-los às nossas condi ções de trabalho.

\section{2 .1 - Meio Liquido de Transporte - MLIr}

Este meio foi uitilizado para o transporte das amostras clinicas e baseou-se no meio $A .3$ x b preconizado por SHEPARD ${ }^{114}$. Sua composição, com algumas modificações, é à seguinte para $100 \mathrm{~mL} \mathrm{p} / \mathrm{v}$ :

Digestão pancreätica de caseina $\ldots \ldots \ldots \ldots \ldots 1,7 \mathrm{~g}$

Digestão papaica de soja ............... 0,3 g

Dextrose ........................... $25 \mathrm{~g}$

Cloreto de södio ......................, g g g

Fosfato dipotässico $\ldots \ldots \ldots \ldots \ldots \ldots \ldots, 25 \mathrm{~g}$ 
Agua deionizada e bidestilada ........... g9 g

Lloriarato de L-cisteina, estérii,

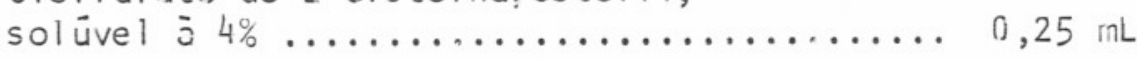

- Após autoclavazem a $12.19 \mathrm{C}$ por 20 minutos, foram adi cionados esterilmente:

Fração de soro PPLO $\ldots \ldots \ldots \ldots \ldots \ldots \ldots \ldots, 1 \mathrm{~mL}$ **

Anfotericina $B \ldots \ldots \ldots \ldots \ldots \ldots \ldots . \ldots . \ldots 2,5 \mu \mathrm{g} / \mathrm{mL} * *$

Penicilina G potässica .............. 1.000 U.I./mL***

$0 \mathrm{pH}$ do meio foi ajustado para 6,0 utilizan do-se solução de $\mathrm{HCl} 2 \mathrm{~N}$.

** As a.lterações processadas foram as seguin tes: introđução de fração de soro, da anfotericina B e da penicilina G potássica.

o material clínico colhido com "swab" foi inoculado imediatamente no meio de transporte MLTr e manti do em banho de gelo atë o momento da semeadura em meio sólido.

2.2.2 - Meio líquido Ltilizado para cultivo do Ureaplasma urealyticum MIU

A elaboração deste meio baseou-se no meio U10 reportado por SHEPARD ${ }^{13}$, ao qual introduziu-se uma pequena modificação, ficancio sua composição para $100 \mathrm{~mL}(\mathrm{p} / \mathrm{v})$ a seguinte: 
Caldo PPLo $\ldots \ldots \ldots \ldots \ldots \ldots \ldots \ldots \ldots \ldots \ldots, 4,4 \mathrm{~g}$

Água deionizada e bidestilada ........... ic nit

- O pH do meio foi ajustado para 5,5 com solução de HC1 $2 \mathrm{~N}$.

Apös a autoclavagem a $1219 \mathrm{C}$ por 20 minutos foram adi cionados esterilmente, os seguintes elementos:

Soro estëril e ncrmal de cavalo .......... 20 mL

Extrato de levedura à $25 \% \ldots \ldots \ldots \ldots \ldots \ldots 10 \quad \mathrm{~mL}$

Cloridrato de L-cisteina à $2 \% \ldots \ldots \ldots \ldots \ldots, 5 \mathrm{~mL}$

Solução de urēia à $10 \% \ldots \ldots \ldots \ldots \ldots \ldots \ldots, 0,5 \quad \mathrm{~mL}$

Suplemento $v x \ldots \ldots \ldots \ldots \ldots \ldots \ldots \ldots, 0 \ldots \ldots, 1,0 \mathrm{~mL} * *$

Penicilina G potässica .................. 000 U.I./mL

Vermeiho de fenol à $1 \% \ldots \ldots \ldots \ldots \ldots \ldots \ldots, 0,1 \mathrm{~mL}$

$0 \mathrm{pH}$ final do meio ajustado para $6,0 \mathrm{com}$ so lução de $\mathrm{HCl} 2 \mathrm{~N}$.

** Como modificação do meio original introdū ziu-se o suplemento Vx.

Foi inoculado $0,1 \mathrm{~mL}$ do meio MLTr contendo a amostra clinica, no meio $\mathrm{MIJU}$, o qual foi incibado à $37 \% \mathrm{C} \mathrm{em}$ mícroaerofilia.

o crescimento do Ureaplasma Urealyticum nes te meio foi evidenciado pela turvação característica do meio e pela mudança da cor de amarelo para púroura, o que ocorria ậō 18-24 horas de incubação, devido à elevação do pH decorrente da hidrólise da uréia atravēs da urease, resultando na produção de amônia. Constatado o crescimento, repiques foram feitos para outros tubos de meio MLU e para 
meio sólido MSM com a finalidade de manutenção da cepa $€$ de isolamento das colonias de ureaplasmas, respectivamente.

\section{2 .3 - Meio liquido para cultivo de Mycopiasmas no trato geniturinärio, que hidrolizam a argini- na, tais como: Mycoplasma hominis e Mycoplasma termentans: MLA}

Este meio foi empregado conforme recomendações do LDMI ${ }^{103}$ (Latoratory of Diagnosis of Mycoplasmas Infeccions), tendo-se suprimido da formulação original a Polimixina, a Anfotericina B e a Exitromicina; ficando a sua composição como se segue:

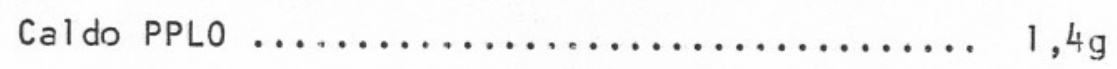

Ạcua deionizada e bidestilada ............ $70 \mathrm{~mL}$

- Apös a autoclavagem à 1219 C por 15 minut. foram adicionacios de mocio estéril:

Soro estëril e normal, de cavalo .......... $20 \mathrm{~mL}$

Extrato de levedura à $25 \% \ldots \ldots \ldots \ldots \ldots \ldots, 10 \mathrm{~mL}$

Cloridrato de L-arginina(solução à $30 \%$..... $0,66 \mathrm{~mL}$

Suplemento $v x \ldots \ldots \ldots \ldots \ldots \ldots \ldots \ldots \ldots \ldots \ldots \ldots \ldots \ldots, 1,0 \mathrm{~mL}$ *

Verme tho de fenol à $2 \% \ldots \ldots \ldots \ldots \ldots \ldots \ldots, 0,1 \mathrm{~mL}$

Penicilina G potässica ............... 1.000 U.I./mL

o pH final do meio foi ajustado para 7,0 so lução de $\mathrm{NaOH}$ IN.

* Introduziu-se ä fórmula o suplementoo VX. 
Após semeadura de $0,1 \mathrm{~mL}$ do meio contendo o inóculo no meio ivita, o mesmo foi incibaco à 3700 por $24-40$ horas em microaerofilia. Os micoplasmas que possujam o sis tema enzimätico, arginina deidrolase, hidxolizaram a arginina com produção de amônia, acarretando uma elevação do pH, com consequente alteração da cor do meio, de róseo à purrẹu ra. Esta alteração de cor em conjunto com a turvação do mes mo caracterizava o crescimento

\subsection{4 - Meio líquido empregacoo na determinação da fer mentação da glicose: MLG}

Este meio baseou-se no preconizado por ALUOTrO ${ }^{2}$ e sua composição foi a șeguinte:

Caldo de cērebro e coração ............ 3,26g

Agua deionizada e bidestilada ........... $88 \mathrm{~mL}$

- 0 meio foi autoclavado a 121 9 c por 15 minutos. Adício nou-se posteriormente de maneira estéril:

Fração de soro PPLO $\ldots \ldots \ldots \ldots \ldots \ldots \ldots, 1,5 \mathrm{~mL}^{\mathrm{a}}$

Glicose, solução estēril à $10 \% \ldots \ldots \ldots \ldots \ldots 10 \mathrm{~mL}$

Vermelho de fenol, solução à $1 \% \ldots \ldots \ldots \ldots, 5 \mathrm{~mL}$

0 pH do meio foi ajustado para 7,6 com auxilio de solução de $\mathrm{NaOH} 1 \mathrm{~N}$.

Blocos cortados do meio sälido contendo cres cimento do micoplasma, foram colocaäos neste meio e o mes 
mo inclubado a 3790 por 24-48 horas.

ヨ Para evitar-se qualquer queda de $\mathrm{pH}$, devido a uma metabolização pelos micoplasmas de outros procutos que não a glicose, foi suprimido do meio bäsico o extrato de le vecura e introduzida a fração de soro pplo em lugar do so ro total de cavaloiol.

A adição de vaselina estēril ao tubo de MLG contendo o micoplasma em estudo, teve como finalidade pro piciar condições de anaerobiose para que ocorresse a fer mentação da glicose, evidenciada pela mudança da cor do meio de vermelho para amarelo, como resultado da formação de ácí do.

\subsection{5 - Meio sólido utilizado no isolamento de Ureaplasma urealyticum e de cutros micoplasmas genitais: MSM}

O meio utilizado foi o mio A7 de SHEPARD ${ }^{114}$. Sua composição para $100 \mathrm{~mL}$ de meio(p/v) foi a seguinte:

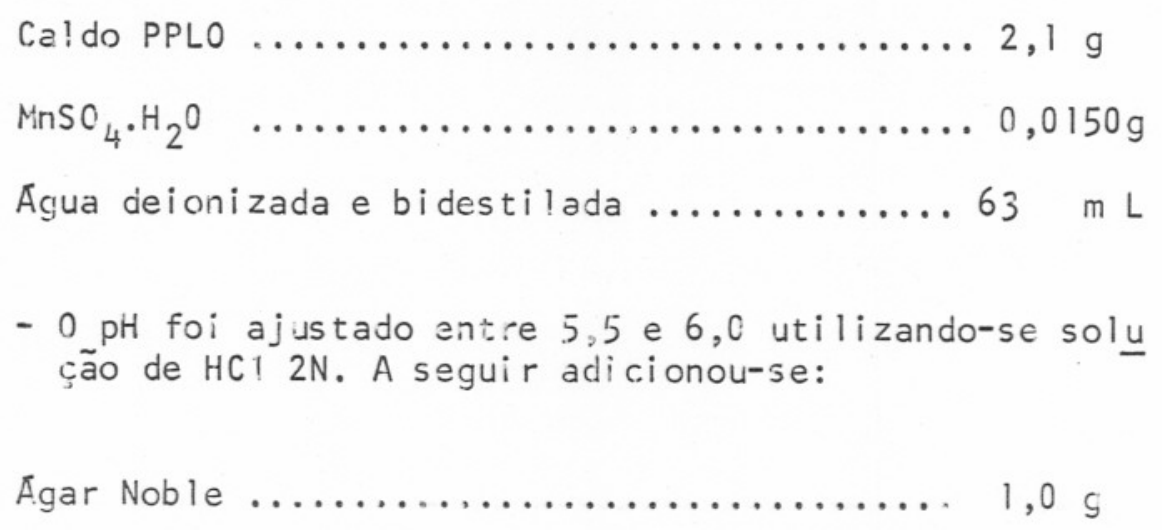


- Apös a aucoclavagern a 121 @ por 15 minutos foran adi cionados esterilmente:

Soro estëril e normal de cavalo ......... $20 \mathrm{~mL}$

Extrato de levedura à $25 \% \ldots \ldots \ldots \ldots \ldots \ldots$. 10 m!

Solução de urēià à $10 \% \quad \ldots \ldots \ldots \ldots \ldots \ldots \ldots$. 1 mL

Solução de glicose à $10 \% \ldots \ldots \ldots \ldots \ldots \ldots \ldots . \ldots \ldots$

Suplemento $V x$.................... 1,0 $\mathrm{mL}^{*}$ *

Penicilina G potässica ................000 U.I./mL

* Foi adicionado à formulação original o suplemento VX.

Apōs a semeadura de 0,lm do material clínico contido em meio MLTr, no meio sōlido MSM,o mesmo foi in cubado à 37ọ em microaerofilia.

O aparecimento, neste meio, de colonias com aspecto de "ovvo frito", apoos 48--72 horas exa indicativo de provävel presença de micoplasmas. Os ureaplasmas foram evi denciados pela morfologia colonial caracteristica de colônias pequenas de cor marrom-dourado devido à formação de $\mathrm{MnO}_{2}$ em presença de amönia proveniente da degradação da urëia pela ação da urease, em 18-24 horas apōs semeadura.

2.2 .6 - Meio sólido utilizado para a redução do tetra zólion: $\underline{\text { MSTz }}^{(2)}$

A composição deste meio para $100 \mathrm{~mL}(\mathrm{p} / \mathrm{v})$ foi a que segue: 
Agar infusão de coraçào $\ldots \ldots \ldots \ldots \ldots \ldots \ldots . \ldots 2,96 \mathrm{~g}$

Água deionizacia e bidestilada .............74 mL

- Apös autoc! avagem por 15 minutos à $121 \% \mathrm{C}$, adicionam-se esteri imente:

Soro estëril e normal de cavalo ............20 mL

Extrato de levedura, solução à $25 \% \ldots \ldots \ldots \ldots, 5 \mathrm{~mL}$

Solução à $2 \%$ de $2,3,5$ cloreto de

trifenil tetrazölio ..................... i mL

$0 \mathrm{pH}$ final do meio foi ajustado para 7,0 com solução de $\mathrm{NaOH}$ IN.

A identificação presuntiva foi feita baseando-se na capacidade que certos micosplasmas possuem, de re duzir o 2,3,5, cloreto de trifeniltetrazólio, dando origem a um composto vermelho tijolo=(formazan).

A prova foi executada tänto em aerobiose co mo em anaerobiose e a tëcnica de semeadura foi a denominada "pushing block", que consistia em reccrtar pequenos blo cos do meio MSM com crescimento e com a face contendo o mi coplasma voltada para baixo, "deslizando-os" sobre a super fície do meio MSTz.

o aparecimento de una cor vermelho tijolo em dois a três dias, ao redor da área cao bloco com crescimento era considerada reação positiva. 


\subsection{7 - Meio sólido utilizado para a determiração da atividade da fosfatase: MSAF}

Este meio baseou-se no inj́cialmente descrito por ALUOTYO em $1970^{2}$, com lima modificação no substrato: a fenolftaleina difosfato de sódio sendo substituída pelo p-nitrofenilfosfato e mantendo-se a estequiometria da reaร̧ão.

A composição final para $100 \mathrm{~mL}(\mathrm{p} / \mathrm{v})$ foi a que se segue:

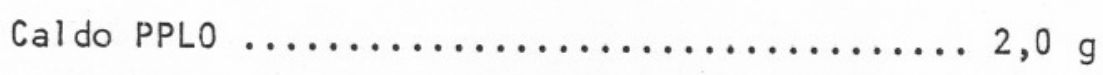

Agua deionizada e bidestilada .........6. 63

- O pH foi ajustado para 5,5a 6,0 com solução de $\mathrm{HCl} 2 \mathrm{~N}$

Agar Noble.$\ldots \ldots \ldots \ldots \ldots \ldots \ldots \ldots \ldots \ldots \ldots \ldots \ldots \ldots$

- Apös autoclavagem à 121 C por 15 minutos foram adicionados esterielmente ao meio:

Soro estëril e normal de cavalo .........20 20 (b)

Extrato de levedura à $25 \% \ldots \ldots \ldots \ldots \ldots \ldots$ 10 $\mathrm{mL}(\mathrm{c})$

Solução de p-nitrofenilfos fato à $1,7 \% \ldots \ldots .0,5 \mathrm{~mL}$ **

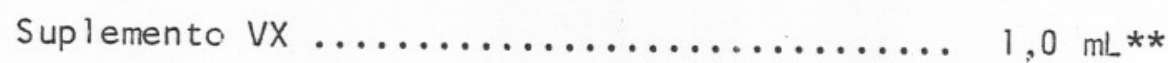

Solução de urēia à $10 \% \ldots \ldots \ldots \ldots \ldots \ldots \ldots$ 1,0 mL

Penicilina G potässica ................ 1.000 U.I. $/ \mathrm{mL}$

** Como modificaçöes do meio original, cittam-se o p-nitrofenilfosfato e o suplemento VX.

(b) e (c) Tanto o soro de cavalo como o ex- 
trato de levedura foram aquecidos por 1 hora à 609C antes de screm adizionados ao meio, a fim de inativar quaisquer eventuais fosfatases presentes nesses componentes.

Após a incubação em microaerofilia à 37\%c por 3 a 4 dias, em caso de reação positiva observa-se o aparecimento de cor amarelo-acastanhada nas āreas de cresci mento. A semeadurá do micoplasma, cuja atividade da fosfatase estava sendo testada, foi feita utilizando-se a tēcni ca do "pushing block" descrita anteriormente.

\subsection{8 - Meio sólido utilizado para a detecção da for- mação de filmes e "spots" - MSFFS}

Deste meio, descrito por FREUNDT ${ }^{44}$, foram su periores alguns componentes e sua composição ficou a seguinte:

Agar infusão de coração $\ldots \ldots \ldots \ldots \ldots \ldots \ldots \ldots$ 3,6 g

Agua deionizada e bidestilada $\ldots \ldots \ldots \ldots 990.60$

- Após a autoclavagem à $1219 \mathrm{C}$ por 20 minutos e resfria mento do meio à aproximadamente 50 ㄷ foram adiciona dos de modo estéril:

Soro estéril e normal de cavalo ......... $20 \mathrm{~mL}$

Emulsão de gema de ovo $\ldots \ldots \ldots \ldots \ldots \ldots \ldots \quad 13,6 \mathrm{~mL}(\mathrm{~g})$

(g) A emulsão de gema de cvo foi preparada pela odição de um volume de emulsão concentrada de gema de ovo a um volume de solução de $\mathrm{NaCl}$ a $0,9 \%$. Foi suprimida do meio original a adição de DNA, acetato de sōdio e penicilina. 
A semeadura do micoplasma em estudo, no meio MSF'H, foi feita a partir de O,imL do cuitivo em meio iî quido, ou de $0,1 \mathrm{mi}$ de caldo de cultura contendo blocos com crescimento, previamente incubado nas condições ideais de semeadura por 72 horas.

Uma vez semeado o micoplasma em estudo nesse meio (NSFFS), e incubado por dois a três dias à $379 \mathrm{C}$ em mi croaerofilia, a reação foi considerada positiva quando se observava o fenōmeno da formação de filmes e "spots".

- Verificação sobre condições de preparo de alguns dos com ponentes dos meios líquidos e sólidos:

a) o soro de cavalo empregado nos vários meios foi inativado à 56 @ por 30 minutos e filtrado em membrana Millipore $0,20 \mu \mathrm{m}$ de diâmetro de poro.

b) O extrato de levedura à 25\% foi elaborado de acor do com a técnica preconizada pelo Laboratory Diagnosis of Mycoplasma Infections.

c) As soluções de uso bem como as substāncias para en riquecimento, antes de serem incorporadas aos meios, foram toc̉as esterilizadas atravēs da filtração em membranas Millipore $0,2 \mu \mathrm{m}$.

d) Os meios liquidos preparados foram, depois de pron tos, filtrados em membranas Millipore $0,20 \mu \mathrm{m}$ e distribuidos em alíquotas de $3 \mathrm{~mL}$, em tubos ( $130 \mathrm{~mm}$ por $10 \mathrm{~mm}$ ), rosquea dos com tampa de baquelite. De cada partida de meio, um tuㅡ bo foi incubado nas condições de semeadura (estufa à 37̣̣ e 
jarra com vela) para teste de esterilidade.

e) Todos os meios sólidos preparados foram distribuí dos em placas estēreis (60mm por $12 \mathrm{~mm})$. Uma placa de cada partida do meio foi incubada nas mesmas condições de semea dura para controle de esterilidade.

\section{3 - TESTE DE SENSIBILIDADE A DIGITONINA}

Uma vez estabelecidos os meios mais adequados que per mitiram $\circ$ isolamento dos micoplasmas a partir das amostras clínicas, foi utilizado o teste de sensibilidade à Digito nina à 1,5\%. Este teste foi realizado por se consitituir um elemento essencial, embora indireto, na identificação e clas sificação taxonômica destes microrganismos, podendo desta maneira separar os acholeplasmas (saprófitas que não neces sitam de esteróis) de outros micoplasmas, incluindo as es pëcies dos gêneros Mycoplasma e Ureaplasma as quais requerem esteróis para o crescimento.

Para a realização dessa prova, utilizou-se a metodo logia empregada por FREUNDT ${ }^{46}$ como segue:

- Discos de papel de filtro de $6 \mathrm{~mm}$ de diâmetro foram embebidos com $20 \mu \mathrm{L}$ de uma soluçăo etanólica de digitonina à 1,5\%. Os discos assim preparados foram colocados em est쓰 fa à 37:C por 24 horas até a evaporação completa do álcool. Uma vez secos, os discos foram armazenados à $4 \% \mathrm{C}$ ern fras- 
- Os microrganismos isolados, na fase logarítmica de crescimento foram someados $\in m$ meio MSM e aiscos de aigitona à 1,5\%, forarn colocados sobre a superfície da placa, a qual foi incubada nas condições ótimas de crescimento. A leitura foi feita quando as colônias tornaram-se visiveis sob microscopia de luz oblíqua.

- A largura da zona de inibição foi medida em mm, sen do considerados sensiveis quando os diâmetros da zona de inibição, apresentavam-se maiores ou iguais a $5 \mathrm{~mm}^{46}$.

- Como controle do teste, foram feitas duplicatas das placas inoculadas, colocando-se discos, não impregnados com digitonina, sob as mesmas condições de crescimento simulta neamente com as placas que estavam sendo testadas. Nestas, o crescimento foi verificado por toda a placa, inclusive ao redor do disco.

Após o isolamento dos micoplasmas e a realizaçăo do teste de sensibilidade à digitonina prosseguiram-se os es tudos com a identificação bioquímica dos mesmos, utilizando-se as seguintes provas:

- Fermentação da Glicose

- Hidrólise da Arginina

- Atividade da Fosfatase

- Formação de Filmes e "Spots"

- Redução do Tetrazólio en Aerobiose e Anaerobiose

- Atividade da Urease 
Para tanto usamos os seguintes controles:

\section{Fermentação da Glicose}

a) Controle positivo: M. bermentans ATCC 19989

b) Controle negativo: M. hominis ATCC 23144

\section{Redução do Tetrazólio}

a) Controle positivo (ae): M. pneumoniae ATCC 15492

b) Controle negativo (ae/an): M. hominis ATCC 23114

\section{Hidrólise da Arginina}

a) Controle positivo: M. haminis ATCC 23114

b) Controle negativo: M. pneumoniae ATCC 15492

\section{Prova da Atividade da Urease}

a) Controle positivo: U. urealyticum ATCC 27619

b) Controie negatifo: M. hominis ATCC 23114

\section{Formação de Filmes e "Spots"}

a) Controle positivo: M. fermentans ATCC 19989

b) Controle negativo: M. hominis ATCC 23114

Alēm dos controles positivo e negativo, foram incubą das nas condiçc̃es de semeacura,placas de meio sem inöculo, como controle de meio.

Realizadas as provas bioquimicas, = identifacação fi nal do microrganismo foi possível com a utilização de anti -soros específicos nas reações imunológicas. 
0 anti-soro para M. hominis foi obtido atravēs de imunizações de coelhos utilizando-se a cepa parrãr de Mýcoplasma hominis ArCCC 23114.

\section{4 - OBTENÇÃO DO ANTI-SORO}

\section{Preparo do Antígeno}

o antígeno foi obtido fazendo-se o cultivo da cepa padrão Mycoplasma hominis em meio líquido MLA que teve o soro de cavalo substituído pela fraçäo de soro PPLO (Difco Laboratories, Detroit, Michigan, USA.) a fim de se evitar uma possível formaçäo de anticorpos heteróloģos. Repigues sucessivos da cepa padrão em vários frascos de meio MLA pro piciou um crescimento na concentração antigênica de 1,27 x $10^{7} \mathrm{UFC} / \mathrm{mL}$. Após a obtenção de aproximadamente $500 \mathrm{~mL}$ de cultura do microrganismo, este foi centrifugado à $5.000 \mathrm{~g} \mathrm{a}$ 4.C, por 1 hora. Apös a centrifugação, o sedimento assim obtido foi lavado 3 vezes em solução salina tamponada com. fosfatos (SST) $\mathrm{pH} 7,2(0,01 \mathrm{M})$ a fim de que todo e qualquer traço de meio fosse removido.

Uma vez lavado, o sedimento foi ressuspenso em SST, em concentração ajustada à escala 3 de Mc Farlànd.

O antígeno assim preparado foi utilizado para a imunização dos coelhos. 


\subsection{1 - Imunização dos coelhos}

Foram utilizados dois coelhos aibinos com 07 meses de idade da raça Nova Zelândia. Adoutou-se o esquema de imunização descrito por PERREAU ${ }^{96}$ :

- Colheu-se uma amostra de sangue dos coelhos antes das imunizações, a fim de verificar se estes jä possuíam anticorpos anti-M. hominis. Como não apresentavam anticorpos, os soros foram utilizados como controle negativo.

- A imunização foi feita com emulsão obtida de mistura em partes iguais de adjuvante incompleto de FREUNDT e suspensão de micoplasma (aproximadamente $2 \mathrm{~mL}$ para cada coe 1ho, sendo $1 \mathrm{~mL}$ do adjuvante e $1 \mathrm{~mL}$ do antígeno).

- A mistura assim obtida foi utilizada para injeções subcu tāneas na região do gradil costal, onde um total de 6 pon tos foram inoculados sendo 3 de cada lado.

- Quatro semanas após, iniciou-se uma série de 7 injeçöes intravenosas, uma por semana, apenas com a suspensão do antigeno.

- Após a quinta inoculação foi feita a primeira sangria. Dendo continuidade ao esquema, nas semanas seguintes rej. niciaram-se as inoculaçōes até perfazer 0 total de 7 injeções intravenosas. 
- Uma semana após a [̉lltima imunização, os coelhos foram san grados e procedeu-se a titulaçăo dos soros.

\section{4 .2 - Titulação dos soros imunes obtidos}

A titulação dos soros imunes obtidos foi fei ta utilizando-se a técnica de inibição metabólica(TIM) des crita por PURCELL 97 .

Esta técnica consiste na capacilidade do so ro em inibir o crescimento, com consequente inibição do me tabolismo dos micoplasmas em meio líquido contendo substra to específico para a espécie. O produto da metabolização desse substrato, o qual altera o pH do meio, ë visualizado pela variação da cor do indicador utilizado(vermelho de fe nol). Assim, na presença de anticorpos específicos ocorria a inibição do crescimento dos micoplasmas, reconhecida pe Ia ausência de variação de cor.

Para a titulação de soros anti- M. hominis o meio líquido utilizado foi o MLA cuja concentraçäo de cloridrato de 1-arginina foi de 0,5\% (substrato da espécie).

Inicialmente procedeu-se à titulação do antí geno, a fim de se deterninar uma concentraçäo de uso para a realizaçäo da tēcnica de inibiçăo metabólica. A partir de ciluiçōes seriadas do antígeno em meio de cultura, apōs a incubação nas condições ideais de sem€adura, (37\%.-48hs.) 
avaliou-se a maior diluição capaz ainda de promover cresci mento, com conseçuente mudança de cor.

\section{4 .3 - Técnica de Inibição Metabólica}

Para a realização do teste de inibição metą bólica utilizou-se o antígeno numa concentração quatro vezes superior à mais alta diluição que procedia a mudança de cor.

Uma vez padronizada a concentração do antíge no, procedeu-se a realização do teste propriamente dito:

1 - Em uma placa de plástico de microtitulação de fundo chą to, estéril, colocou-se uma gota $(25 \mu \mathrm{L})$ do meio MLA em cada escavação desde a primeira até a sētima da prime ra fileira, e na nona, como controle do meio.

2 - Acrescentou-se uma gota $(25 \mu \mathrm{L})$ do soro a ser titulado (inativado a 56 c C - 30minutos) somente na primeira e dê cima escavação (controle do soro).

3 - Procedeu-se à diluição do soro, passando-se $25 \mu \mathrm{L}$ da primeira atë a sētima escavação, homogeneizando-se a cạ da passagem.

4 - Foi colocado a seguir duas gotas (50 L) do antígeno pre viamente titulado e diluído em caldo PPLO, em cada escavação, exceto no controle do soro e no controle do meio. 
5 - Após a agitação, a placa foi fechada e incubada a 37 . por dois a três dias em juriú com vela, quando foi feita a Ieitura.

A presença de anticorpos foi detectada nas escavações em que não foi constatada a alteração da cor do meio, o que significa a inibição do crescimento com consequente inibição metabólica.

Nas demais, onde a cor passou de róseo-claro à púrpura, ficava evidenciada a ausência de anticorpos.

Verificados todos os controles e constatado que o sistema apresentou pleno funcionamento, o título foi dado pela maior diluição do soro em que não houve alteração da cor do meio.

A titulação dos imunerosos obtidos atravēs de imunizaÇões, apresentaram baixos títulos e portanto decidiu-se utilizá-los puros para realização das provas sorológicas.

\section{5 - IDENTIFICACุÃO SOROLOGICA DOS MICOPIAASMAS ISOLADOS DAS AMOSTRAS CLINICAS}

A caraterização dos micoplasmas isolados foi feita utilizando-se as técnicas ċe inibição metabólica97 e de imunodirusão dupla em gel de ägar 79,93 .

A imunodifusão dupla tem como finalidade cemonstrar 
a identidade entre sistemas precipitantes e que tem como fundamento a difusão, no ágar, de substâncias solúveis (an tígeno e anticorpo) com precipitação na zona de equivalēncia.

Para tanto, a obtençäo dos antígenos na forma solúvel foi o próximo passo para a realização da imunodifusão dupla.

\subsection{1 - Preparo do antígeno padrão na forma solúvel}

Após o cultivo da cepa pađrão de M. hominis ATCC 23114 em meio líquido MLA, várias passagens sucessivas foram feitas até a obtenção de $500 \mathrm{~mL}$ de cultura de $M$, hominis com uma concentração de $1,27 \times 10^{7}$ U.F.C./mL.

Este volume foi dividido em tubos com capaci dade de $40 \mathrm{~mL}$, por facilidades técnicas.

A seguir, foi feita a centrifugação dos mesmos a $5.000 \mathrm{~g}$ por uma hora e os sedimentos assim obtidos fo ram lavados três vezes com SST (soluçăo salina tamponada pH $7,2-7,4)$. Uma vez eliminado todo e qualquer traço de meio de cultura, os sedimentos foram ressuspensos em SST,até que se obtivesse uma turbidez equivalente ao tubo 2 da escala de Mic Farland.

A fim de se obter o antigeno solúvel, procedei-se ao rompimento celular, através da técnica de conge 
lamento e descongelamento da suspensāo obtida, aliquotada em värios tubos.

o congelamento foi realizado mergulhandoo an tígeno em nitrogênio líquido e o descongelamento era feito colocando-se os tubos imediatamente em banho-maria à 37\%C. A operação foi repetida vărias vezes até o rompimento total das células.

O conteúdo dos tubos foram misturados e homo geneizados a fim de se determinar a concentração protéica, - que foi feito pelo método de LoWRY 81 . A concentração pró téica do antígeno padrão de M. hominis determinada foi de $1,5 \mathrm{mg} / \mathrm{mL}$.

\subsection{2 - Preparo dos antígenos solúveis, a partir dos micoplasmas isolados das amostras clínicas}

O mesmo procedimento utilizado para a obtenção do antígeno solúvel da cepa padrão de M. hominis, foi empregado para a obtenção dos antígenos solúveis isolados das amostras clinicas, partindo-se contudo de $100 \mathrm{~mL}$ de cul tura de cada antígeno. As dosagens protéicas dos antígenos das amostras varjaram de $1,46 \mathrm{mg} / \mathrm{mL}$ a $1,70 \mathrm{mg} / \mathrm{mL}$.

De posse dos antígenos na forma sóluvel(ANTI GENO PADRÃO E ANIIGENO DAS AMOSTRAS CLINICAS)e ainda do an ti-soro anti M. hominis, procedeu-se à realização da reaÇão de imunodifusão dupla de oUCHIERL̃ONY para cada micoplas 
ma. isolado.

\section{5 .3 - Imunodifusão dupla de OUCATERLONY ${ }^{95}$}

A metodologia empregada para a realização da imunodifusão dupla de ouchterionỵ foi a seguinte:

- Lâminas de microscopia, bem limpas, foram recobertas com $1 \mathrm{~mL}$ de ágar à 1\% em água destilada.

- A seguir, as mesmas foram secas em estufa à 37oc por 24 horas.

- As Iäminas assim preparadas foram recobertas com $3 \mathrm{~mL}$ de de ăgar a l\% em solução fisiológica adicionada de mertio lato $1 / 10000$.

- Apōs a solidificação das mesmas, o ágar foi perfurado fá zendo-se sete orificios, sendo um central e os denais des tribuidos simetricamente ao redor.

- No orificio central foi colocado o soro anti M, hominis e nos demais orifícios foi intercalado o antígeno padrão com os antigenos das amostras.

- As Iāminas assim preparadas foram deixadas difundir em càmara úmida, por 48 horas à temperatura ambiente.

- A seguir, as mesmas foram lavadas com soluçäo fisioiógica, realizando-se trocas frequentes (no minimo de 6), por 48 horas. 
- Apös as lavagens, as Iâminas, embrulhadas préviamente em papel de filtro uimedecido, foram secas em estufa ḋ 450̣.

- Uma vez secas, estas foram coradas durante 10 minutos uti zando-se o Ponceau como corante. A seguir procedeu-se à lavagem das lâminas com solução de ácico acético 5\% a fim de remover o excesso do corante.

\section{Leitura e interpretação da reação}

Em caso de identidade antigênica entre 0 mi coplasma padrão e os provenientes das amostras clínicas em presença do soro anti M.hominis, havia a formação de uma linha contínua circular de precipitação.

Em caso dos antigenos serem diferentes entre si, as linhas de precipitação formadas para cada antígeno, apresentariam configuração diferente daquela observada em caso de identidade.

Alēm da realizaçāo de imunodifusão dupla, os micoplasmas das amostras foram tambëm identjificados a.través da reação de inibição metabólica já descrita anteriormente no item 2.5.3. 


\section{5 - TESTE ESTATISTICO}

O teste estatistico empregado para a avaliação das proporções äe isolamento do Ureaplasma urealyticum e de M. hominis nas gestantes pertencentes aos grupos de Risco e Controle, foi o de "Comparação de duas proporções independentes" 21 , utilizando-se um nível de significância de 5 \% $(\alpha=0,05)$. 


\section{3 - RESULTALCSS}

\section{1 - Padronização Técnica}

Todas as modificações introduzidas nos diferentes meios de cultivo, de transporte, bem como na identificação bioquímica e sorológica, estão apresentados no capítulo de Ma terial e Métodos nas suas formas definitivas, para facilitar aos pesquisadores e profissionais interessados a impian ção ou utilizaçäo dos referidos métodos e obtenção de resul tados satisfatörios.

Assim, fot possivel isoiar o M.hominus e o U. urealyticum do material cervical e identificá-los através da morfologia colonial característica, da prova da sensibilidade à digi tonina a 1,5\%, do comportamento bioquímico frente a alguns substratos e conclusivamente através da sorologia com as rea ções de imunodifusão dupla e da reação de inibição metabólica.

Os micoplasmas isolados apresentaram as seguintes ca racteristicas, expressas no Quadro I: 
QUADRO I

Características morfológicas e bioquímicas dos micoplasmas isolados de amostras clinjcas

\begin{tabular}{|c|c|c|}
\hline Características & Ureaplasma urealyticum & Mycoplasma hominis \\
\hline $\begin{array}{l}\text { Morfologia colonia! } \\
\text { no meio MSM }\end{array}$ & Colônias " $\mathrm{T}$ "* & $\begin{array}{l}\text { Colônias com aspecto } \\
\text { de "ovo frito" }\end{array}$ \\
\hline $\begin{array}{l}\text { Sensibilidade à } \\
\text { digitonina }\end{array}$ & S & S \\
\hline $\begin{array}{c}\text { Metabolização da } \\
\text { gilicose }\end{array}$ & - & - \\
\hline Hidrölise da arginina & - & + \\
\hline $\begin{array}{c}\text { Prova de atividade da } \\
\text { urease }\end{array}$ & + & - \\
\hline $\begin{array}{c}\text { Prova de atividade da } \\
\text { fosfatase }\end{array}$ & + & - \\
\hline $\begin{array}{l}\text { Prociução de filmes e } \\
\text { "spots" }\end{array}$ & - & - \\
\hline $\begin{array}{l}\text { Produçāo de tetrazōlio } \\
\text { em ae/an }\end{array}$ & - & - \\
\hline
\end{tabular}

* $T=$ Colônias diminutas apresentando colcração marrom dourado $S=$ Sensível

$(-)=$ Negat $i$ vo

$(+)=$ Pos i tivo 


\section{2 - Identificação das espécies lireaplasma urralyticum e ingcopiasma huminis nas arosiras cínicas}

A caracterização do Ureaplasma urealyticum foi feita pela observação da morfologia colonial característica no meio MSM e atravēs de provas bioquímicas. No meio MSM o Ureaplasma urealyticum apresentou-se como colônias diminu tas de coloração marrom dourado conforme ilustradas nas fi guras 1 e 2. A atividade da fosfatase foi positiva como o é sempre para este gēnero, apesar de não ser exclusiva, uma vez que outros micoplasmas genitais também a possuem. As provas de metabolização da glicose, hidrólise da arginina, prova de redução do tetrazōlio e formação de filmes e "spots" foram sempre negativas. Todas as culturas de lireaplasma urealyticum mostraram-se sensíveis à digitona. A prova mais importante, entretanto, na identificação do Ureaplasma urealyticum foi a da atividade da urease, pois dentre os Micoplasmata les apenas o gênero Ureaplasma tem essa atividade.

Todos os microrganismos isolados do material clínico, que apresentavam as caracteristicas acima, foram identifi cados como Ureaplasma urealyticum.

A identificação presuntiva dos M. hominis foi feita pela morfologia colonial caracteristica com aspecto de "ovo frito" no meio MSM (figura 3), e pelo comportamento bioquí co. Todos os isolados apresentaram: sensibilidade à dj.gitonina, prova de arginina positiva, e as seguintes provas negativas: metabolismo da glicose, da atividade da urease 


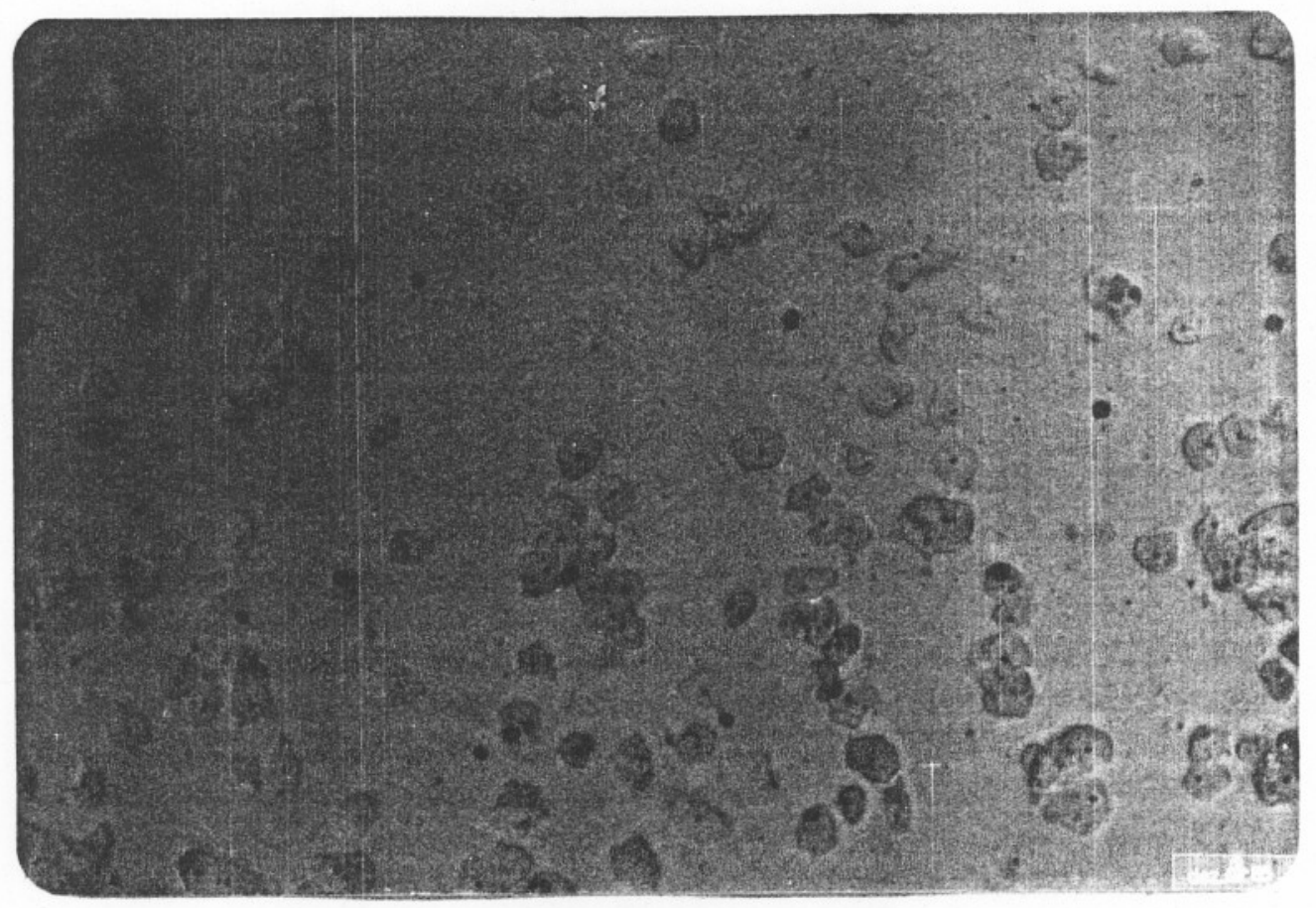

Fig. 1 - Colōnias de Ureaplasma urealyticum em meio sōlido MSM (Aumento de 100x)

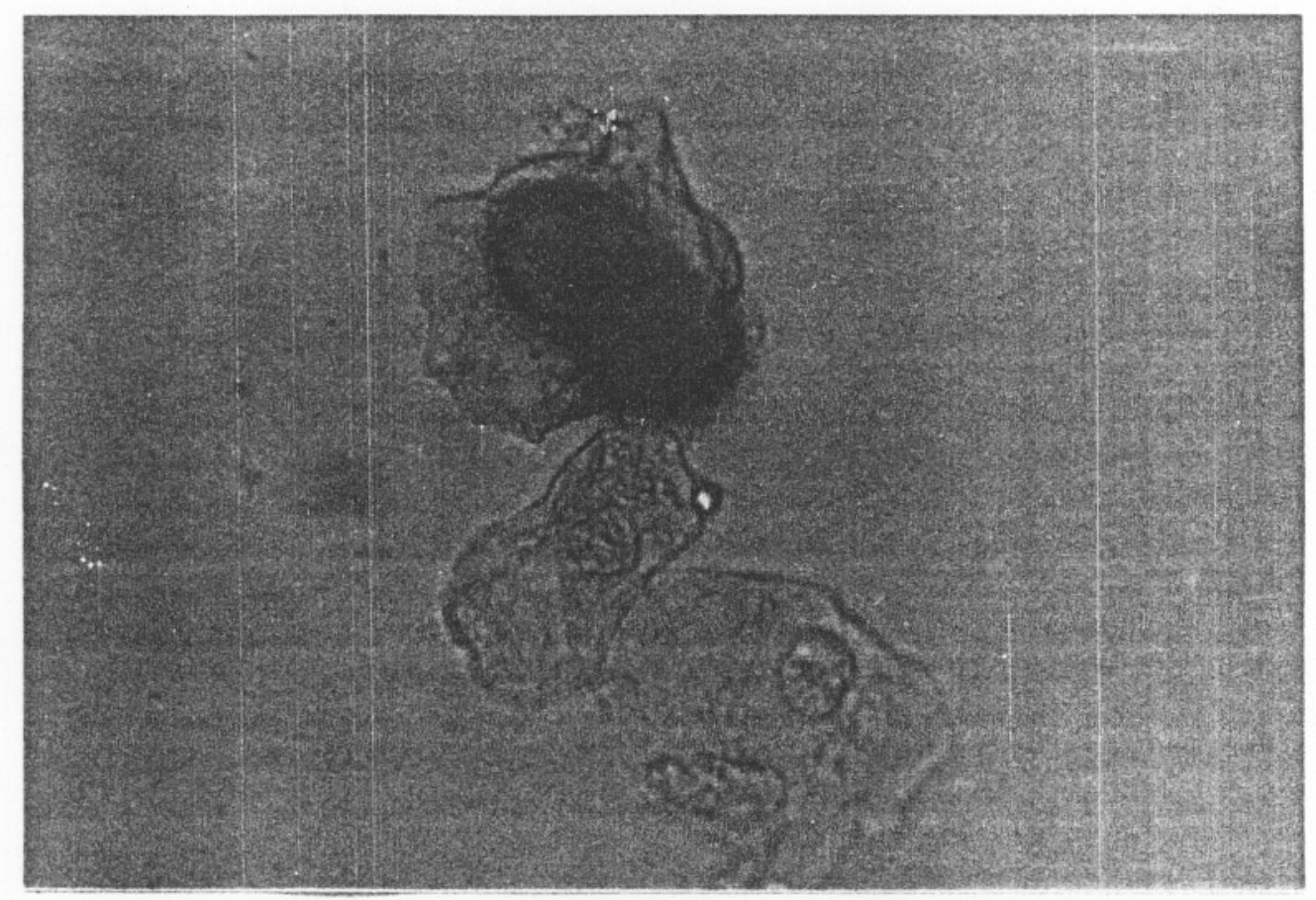

Fig. 2 - Colônias de Ureaplasma urealyticum sobre a super fície de células epiteliais da mucosa servical. 9 (Aumento de 400x) 


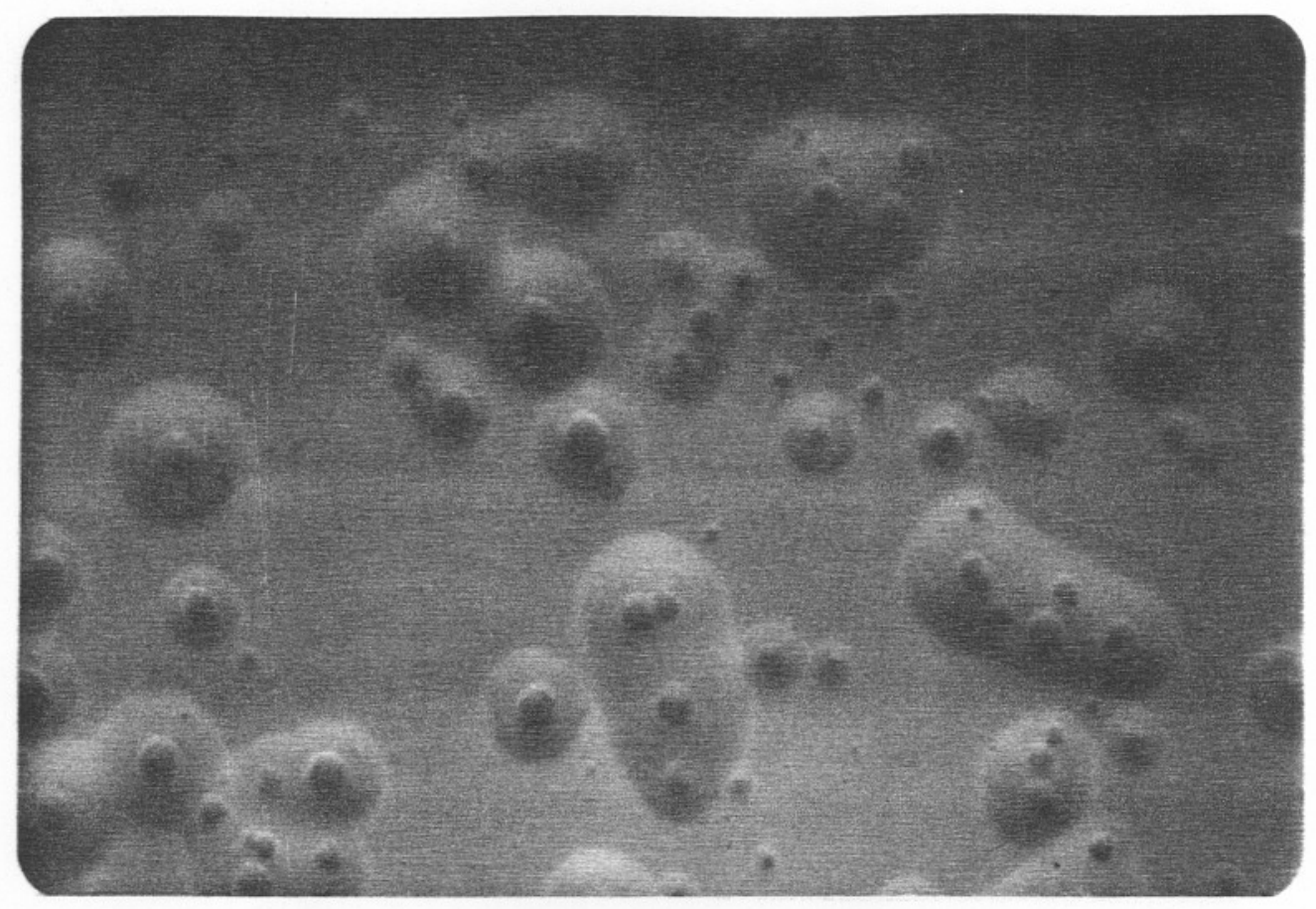

Fig. 3 - Colōnias de Mycoplasma hominis em meio sölido MSM. (Aumento de 100x)

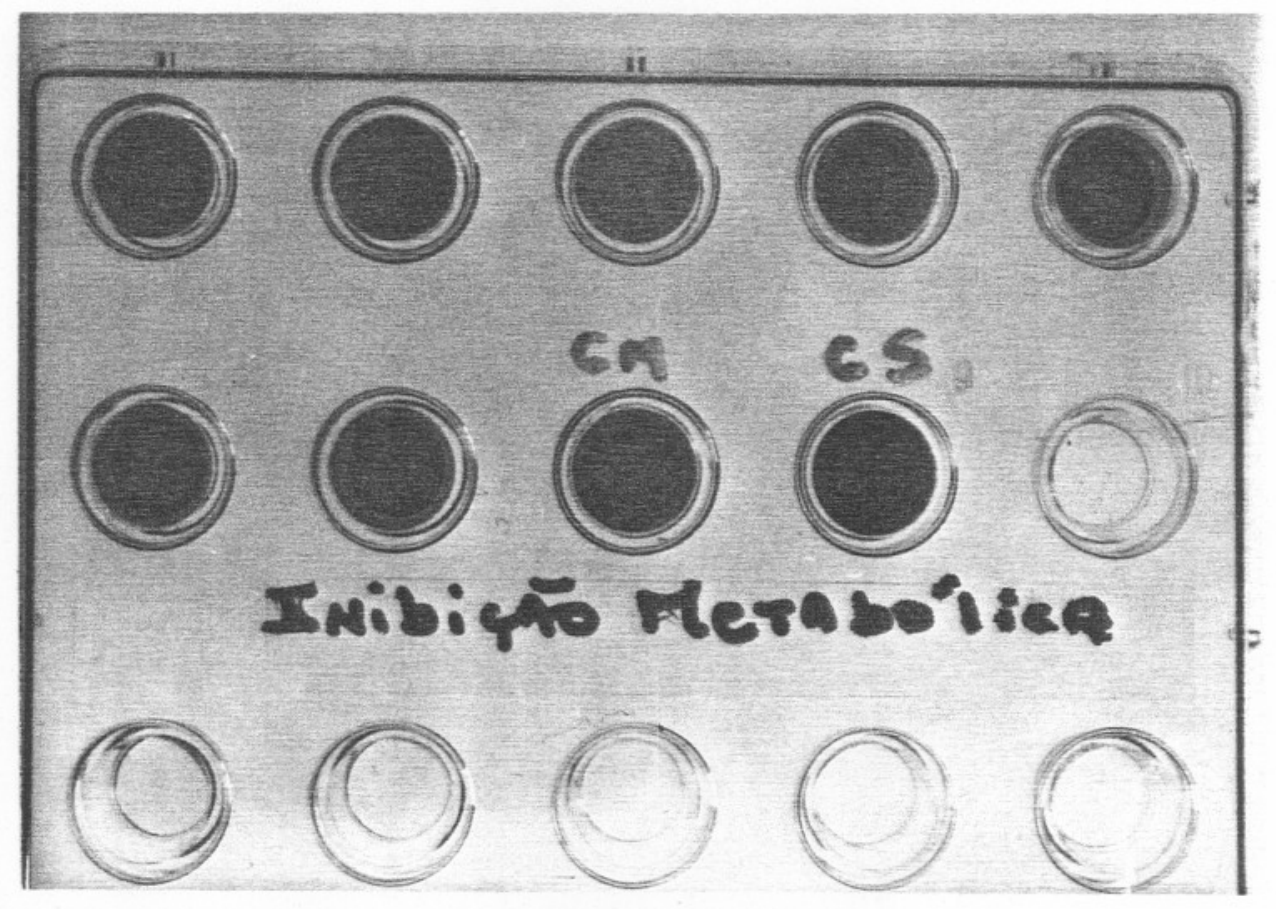

Fig. 4 - Prova de Inibição Metabölica empregada na titulação do soro imune obtido, bem como na identificação dos micoplasmas isolados.

( $C S=$ controle do soro; $C M=$ controle do meio $M L A$ ) 


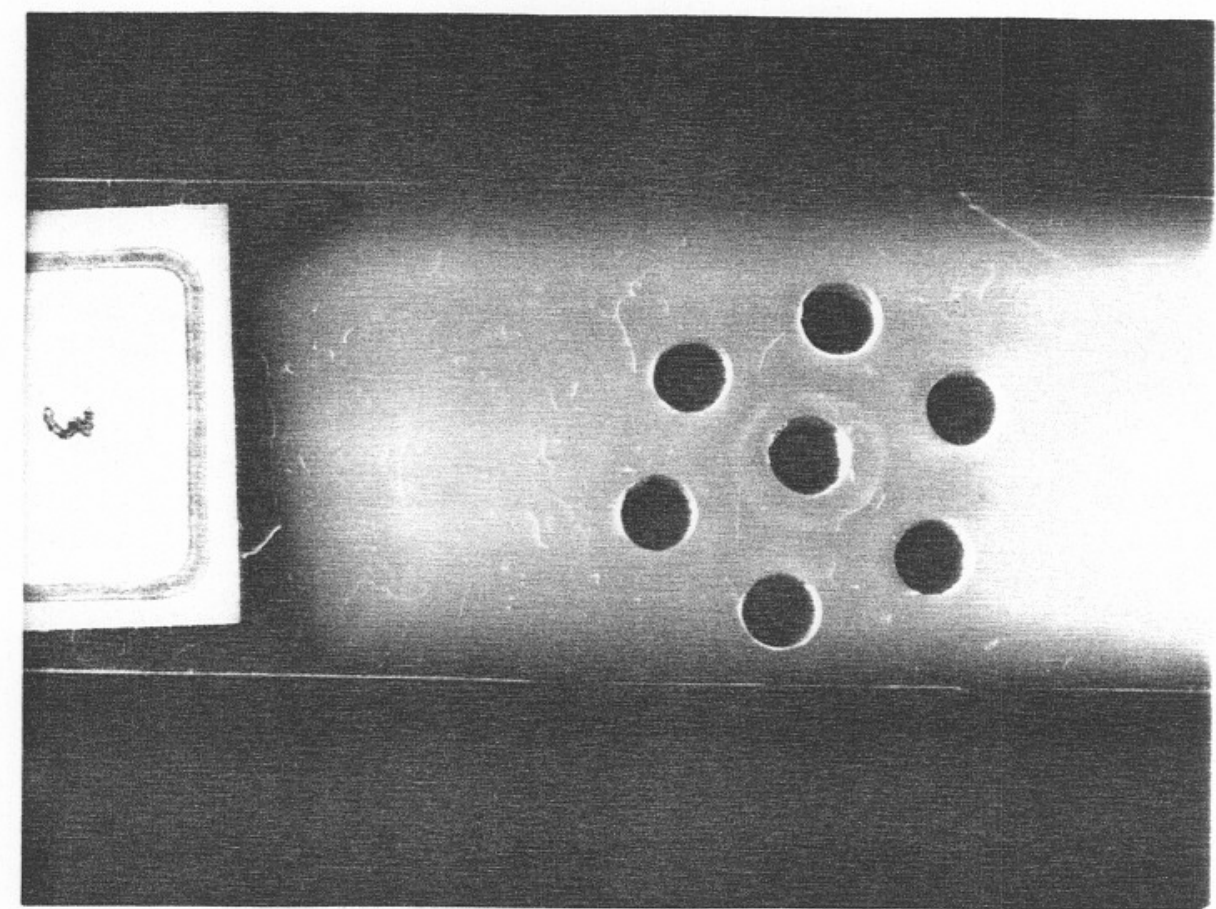

Fig. 5 - Imunodifusão dupla de OUCHTERLONY em gel de āgar. Linha de identidade podem ser observadas ao redor do orifício central contendo soro imune anti- $M$. hominis.

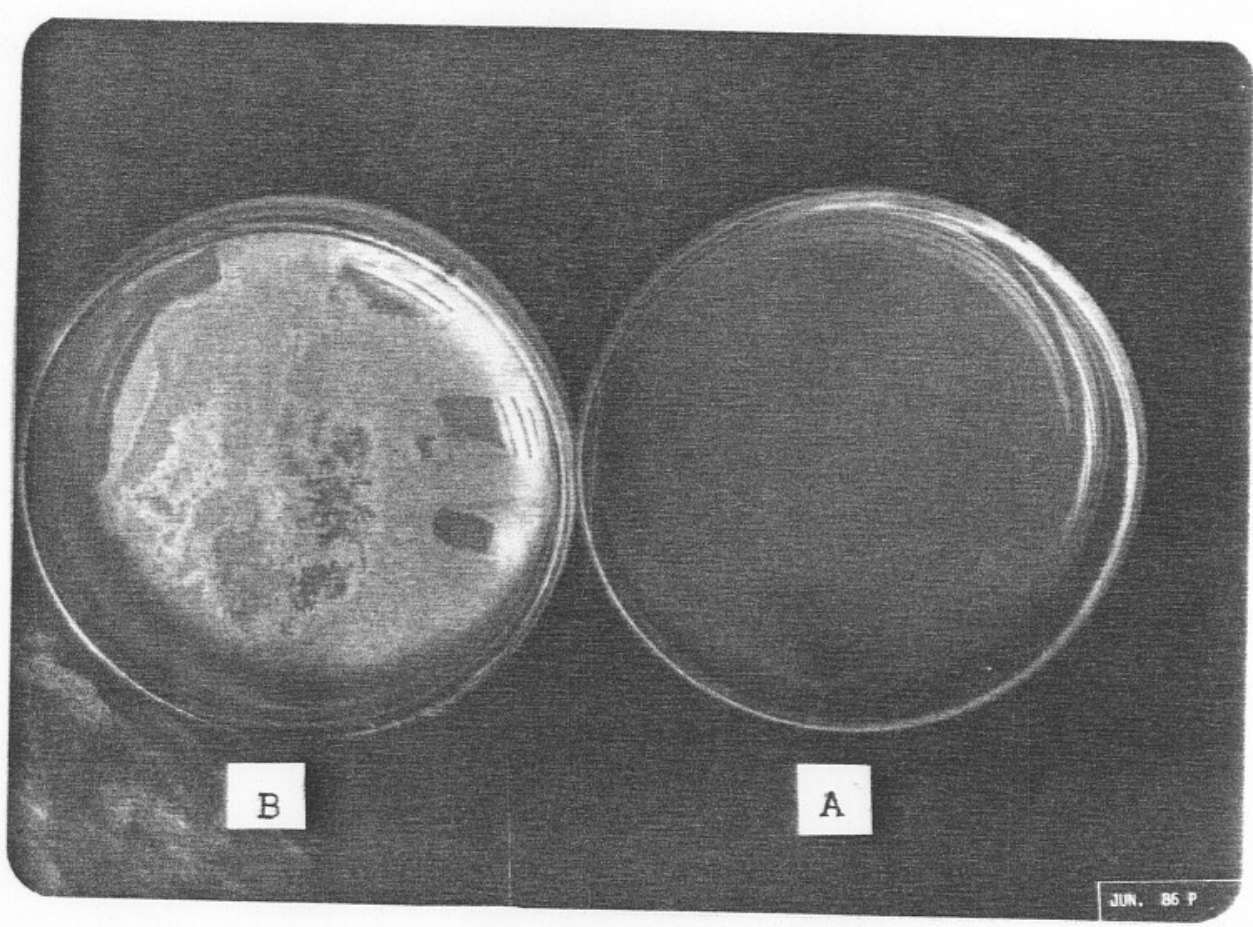

Fig. 6 - Prova utilizada na detecção do fenômeno de Formação de filmes e "spots". A = controle negativo $e$ $B=$ controle positivo - M. fermentans 19989 ATCC 
e da atividade dà fosfatase, da redução do tetrazólio,e da fornaçäo do filmoa o "spots" conforme figura 6. A identifi caçäo final do $H$. homiris foi feita somente apōs os testes soroıógicos de imunodisusão dupla e ãe inj.bição metabōıica, os quais podem ser observados nas figuras 4 e 5 respectiva mente.

\section{3 - Isolamento do Ureaplasma urealyticum e do Mycoplasma hominis em amostras clínicas}

$\mathrm{Na}$ tabela I podem ser observados os resultados do isolamento de micoplasmas de amostras clínicas de 74 (seten ta e quatro) gestantes estudadas, sendo 37 (trinta e sete) pertencentes ao grupo de risco e 37 (trinta e sete) ao gru po controle. Das amostras clínicas colhj.das de trinta e se te gestantes do grupo de risco, vinte e umā $(56,8 \%)$ foram po sitivas para Ureaplasma urealyticum, duas $(5,4 \%)$ para Myco plasma hominis e de seis $(15,2 \%$ ) pacientes puderam ser iso lados anbos os microrganismos: Ureaplasma urealyricum e Mycoplasma hominis. Nesse grupo oito amostras (21,6\%) mos traram-se negativas para a pesquisa de micoplasmas. No gru po controle foram isoladas dezoito anostras $(48,6 \%)$ de Ureaplasma urealyticuin: Mycoplasma hominis não foi isolado de nenhuma amostra $(0,0 \%)$ e em seis pacientes pode ser eví denciada a presença simultânea de ambos os microrganismos. Em treze amostras desse grupo (35,1\%), a pesquisa de rnico 
TABELAA I

Frequência de Ureaplasma urealyticum e/ou Mycoplasma hominis no trato geniturinário de gestantes

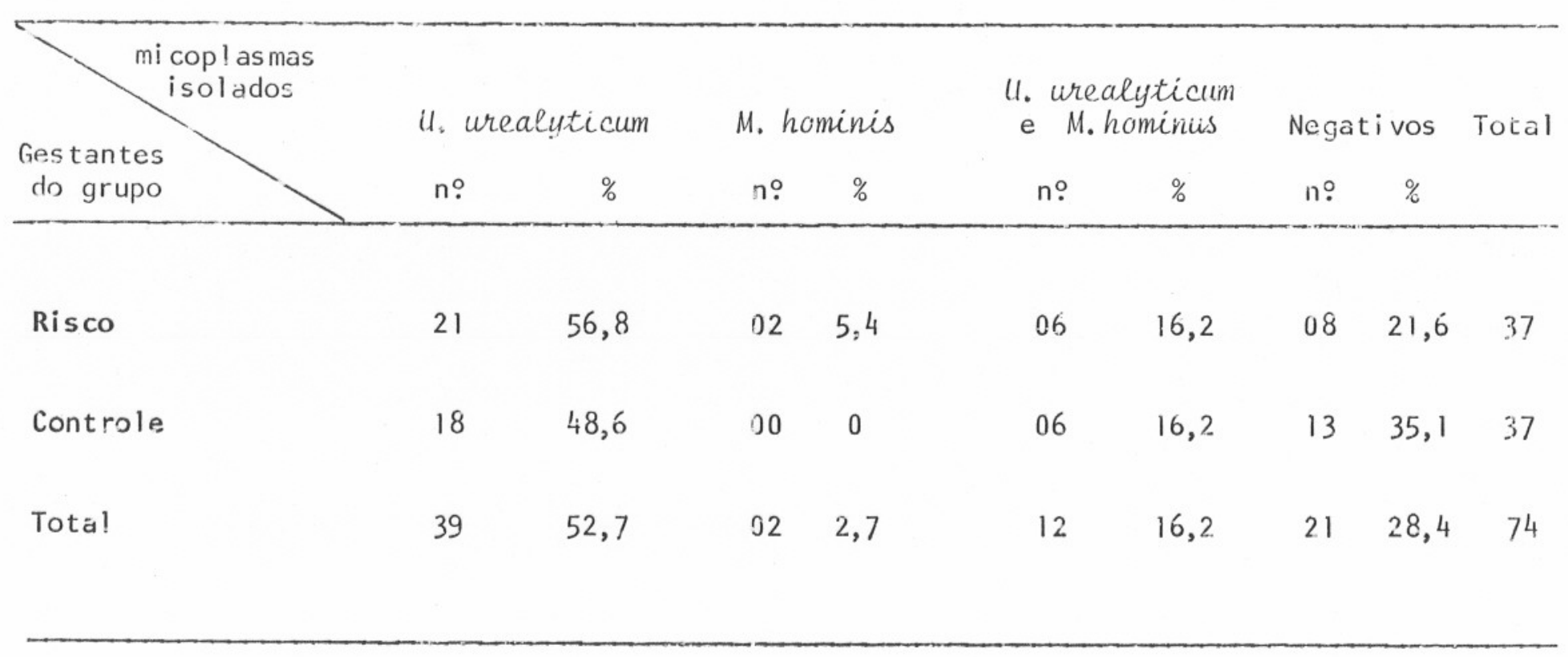

- Resultados do isolamento de mi coplasma de amostras clínicas de 74 gestantes, sendo 37 pertencentes ao grupo de risco e 37 ao grupo controle. 
plasmas resultou negativa. 0 totäl de isolamentos de Ureaplasma ureaxyicum rios dois grupos foi portanto de trinta e nove $(52,7 \%)$; Mycoplasma hominis foi encontrado em duas amostras $(2,7 \%) \in$ em doze $(16,2 \%)$ observamos a preserça de ambos. 0 número de amostras negativas no grupo de risco foi de oito $(21,6 \%)$ e no grupo controle foi de treze (35,1\%), perfazen do um total de vinte e um $(28,4 \%)$ casos negativos nos dois grupos.

o nümero total de isclamentos de Ureaprasma urealyticum e Mycoplasma hominis nos grupos estudados estã apresentado na tabela II.

Essa tabela traduz o número total de isolamentos de Ureaplasma urealyticum e de Mycoplasma hominis no grupo de risco e no grupo controle, em 74 amostras.

No grupo de riscc foram obtidos: vinte e set.e $(73,0 \%)$ isolamentos de Ureaplasma urealyticum $\in$ oito $(21,6 \%)$ isola mentos de Mycoplasma hominis, resultando trinta e cinco $(94,6 \%)$ isolamentos de micoplasma nesse grupo. O grupo con trole apresentou: vinte $\in$ quatro $(65,0 \%)$ a isolamentos de Ureaplasma urealyticum e seis $(16,2 \%)$ de Mycoplasma hominis, perfazendo trinta $(81,2 \%)$ isolamentos de micoplasmas no grupo.

Portarto o númerc total de isolamentos, nos dois gru. pos, de Ureaprasma urealuticum foi de cinquenta e um (68,9\%) e de Mycoplasma hominis de quatorze $(1.8,9 \%)$, resultando ses senta e cinco $(87,8 \%)$ isolamentos de micoplasmas. 
TABELAA I I

Ureaplasma urealyticum e Mycoplasma hominis

isolaủos do trato geniturinärio ros grupos de risco e controle $(n=74)$

\begin{tabular}{|c|c|c|c|c|c|c|}
\hline \multirow[b]{2}{*}{ Gestantes } & \multicolumn{2}{|c|}{$\begin{array}{l}\text { Ureaplasma } \\
\text { wiealyticun }\end{array}$} & \multicolumn{2}{|c|}{$\begin{array}{c}\text { Mycoplasma } \\
\text { hominis }\end{array}$} & \multicolumn{2}{|c|}{$\begin{array}{c}\text { Total de } \\
\text { isolamentos }\end{array}$} \\
\hline & $\mathrm{n}$ ? & $\%$ & $\mathrm{n}$ ? & $\%$ & ne & $\%$ \\
\hline Grupo de risco & 27 & 73,0 & 08 & 21,6 & 35 & 94,6 \\
\hline Grupo de controle & 24 & 65,0 & 06 & 16,2 & 30 & 81,2 \\
\hline Totaì & 51 & 68,9 & 14 & 18,9 & 65 & 87,8 \\
\hline
\end{tabular}

- Nümero total de isolamentos de Ureaplasma urealyticum e de Mycoplasma hominis no grupo de risco e grupo de controle. 


\section{4 - Anälise Estatística}

A análise estatística das tảelas ì e II mostran que:

- A prevalência de Ureaplasma urealyticum verificacia entre os grupos de risco e controle não foi significativamente djferente, em vista c̈e ter sido encontrado um $Z=0,7$. Por tanto, sendo ${ }^{2}$ crítico $2,5 \%=1,96$ nossos achados indicam a inexistēncia de diferença entre as grupos estudados.

- Para a prevaiência do Mycoplasma hominis nos referidos grupos, encontramos um $\mathrm{Z}=0,6$. Portanto, sendo ${ }_{\text {crítico }}$ $>$ Zobtido, podemos verificar que a diferença na propor ção de isolamento não foi significativa entre os dois grupos.

Fizeram parte do grupo de risco, gestantes com alte rações clinicamente definidas, alterações estas que pocieriam ser as causas clinicas do nascimentc de prematuros, de natimortos de abortos repetitivos, enfim, dos problemas conceptuais. A pesquisa de micoplasmas nessas gesiantes resul tou no seguinte: Ureaplasma lirealyticum foi isolado de seis pacientes com incompetência istmo cervical e una que possuía ítero bicórnico, resultanto portanto sete isolamentos de Ureaplasma urealyticum.

A associação Ur.eaplasma urealyticum $\rightarrow$ Micoplasma hominis pode ser observada em duas pacientes com incompetên cía istmo cervical a em uma paciente que possuía ovārio po 
licístico, num total de três isolamentos. Foi negativa a pesquisa da micoplasma or cinco pacientes desse gruno, De um total de 15 (quinze) amostras de micoplasmas isolado, on ze foram de gestantes com incompetência istmo cervical; duas de gestantes com ovário policístico, uma de gestante com ovārio hipoplásico e uma de gestante com ütero bicörnico. A tabela III expressa esses resultados.

\section{5 - Resultados das gestaçöes das pacientes estudadas}

De 62 (sessenta e duas) gestantes, do total de 74 (se tenta e quatrol estudados, foi possivel coletar dados quan to aos resultados das gestações que estavam em curso e ex pressā-los (tabela IV).

Essa tabela permite constatar que dentre as gestantes do grupo c̈e risco, vinte e cinco deram à luz conceptos normais, una teve um malformado, seis tiveram prematuros, duas geraram natimortos e duas abortaram, perfazendo um to tal de trinta e seis conceptos das trinta e sete gestantes pertencentes ao grupo.

Como resultado dás gestações do grupo controle, somente foram obtidos dacios sobre vinte e seis pacientes, e destas, todas derám à luz crianças normais.

O isolamento de micoplasmas $e$ os produtos de concepção no grupo de risco com alterações clinicamente defini- 


\section{TABELA III}

Isolamento de microrganismos de gestantes

apresentando alterações clínicas do trato genital

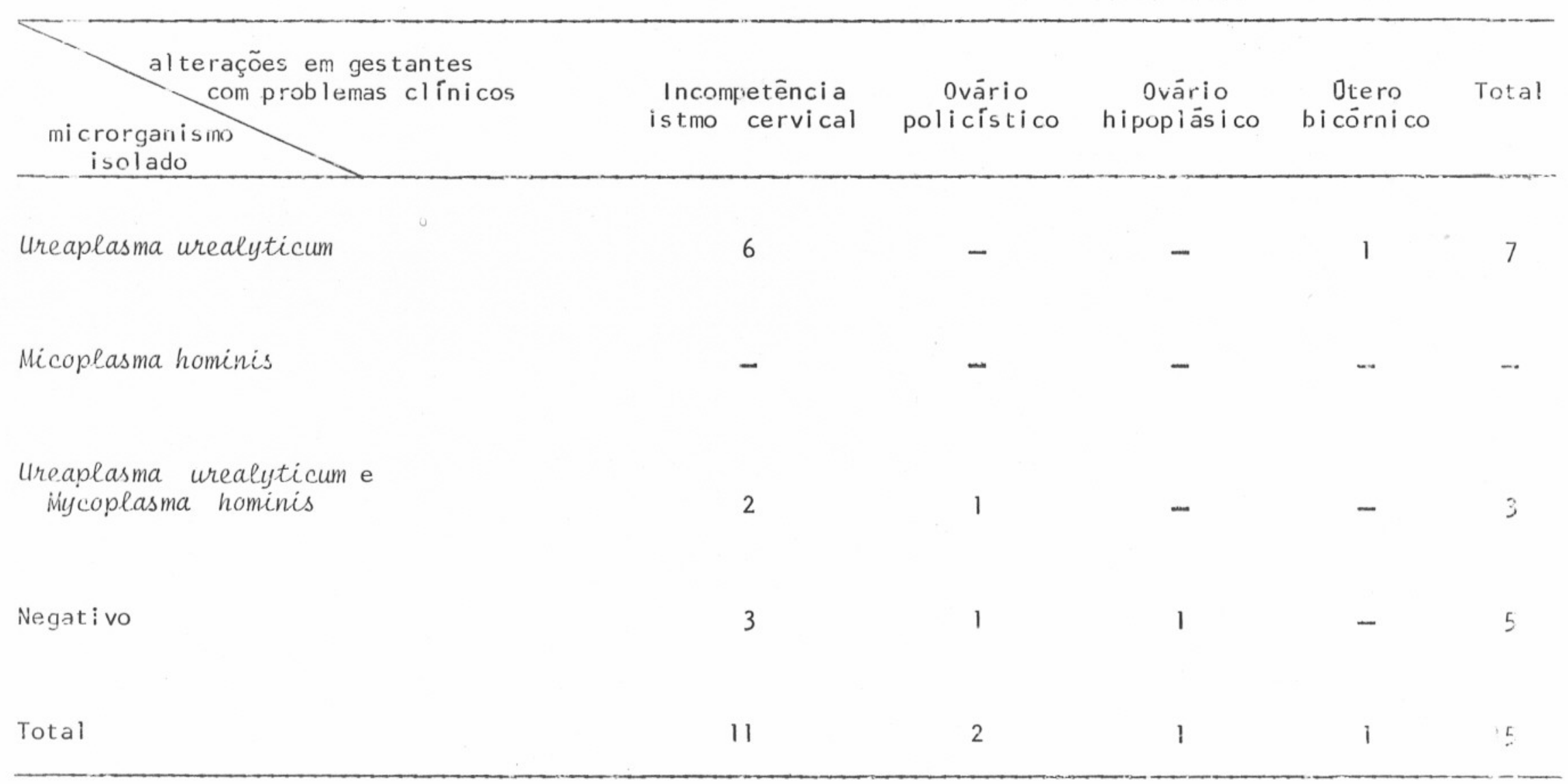


TABELA IV

Dados sobre o produto conceptual nos grupos estudados

$\begin{gathered}\text { resultado } \\ \text { de gestaçăo }\end{gathered}$ RN normal Abortos
Gestantes

- Resultados das gestaçŏes que estavam em curso; grupo de risco e controle.

(?)=não hā regist ro

$(*)=$ são considerados prematuros os nascidos com menos de 37 semanas. 
¿as e no grupo sem alteraçöes poden ser observadas nais tabelas V, VI e VII.

A tabela V fornece dados sobre os micoplasmas isola dos e os produtos conceptuais das onze gestantes com incom petência istino cervical.

Dentre as pacientes em que Ureaplasma urealyticum foi isolado foram observados os nascimentos de: um prematü ro, um malformado e quatro crianças normais, perfazendo um total de seis casos de isolamento de Ureaplasma urealyticum. A associação Ureaplasma urealyticum $\rightarrow$ Mycoplasma hominis foi observada em uma paciente que deu à luz um natimorto e em um caso de nascimento de prematuro; resultando um total de dois isolamentos. Foi três o nümero de casos em que a pesquisa de micoplasmas foi negativa.

A tabela VI fornece dados sobre a anälise de quatro pacientes que, possuf́am como alterações clinicas: útero bị cōrnio, útero hipoplásico e ovário policístico. Dentre es tas, Ureaplasma urealyticum foi isolado da paciente com ütero bicörnio que deı à luz um natimorto, A presença simul tänea de Ureaplasma urealyticum e Mycoplasma hominis foi observada em uma única paciente com ovário policístico e que deu à luz um concepto normal. Não foi isolado micoplasma dà paciente com ütero hipoplásico, a qual abortou, e tampouco da pactente com ovário policístico que deu á luz uma criança normal.

A tabel.a VII permite observar a relaçäo entre os mi coplasmas isolados e as alterações ocorricias no produto con 
TABELA $V$

Microrganismo isolado de pacientes

com incompetēncia istmo cervical e seus produtos de gestação

\begin{tabular}{|c|c|c|c|c|c|c|}
\hline $\begin{array}{c}\text { prodistos } \\
\text { dia concepção } \\
\text { mi crorganis mo } \\
\text { isolado }\end{array}$ & Natimorto & Prematuro & Aborto & Mal formado & Normal & Total \\
\hline Ureaplasma urealyticum & - & 1 & - & 1 & 4 & 6 \\
\hline \multicolumn{7}{|l|}{ lireaplasma urealyiicum } \\
\hline Mycoplasma hominis & $i$ & 1 & - & - & - & 2 \\
\hline Negativo & - & 1 & - & - & 2 & 3 \\
\hline Total & 1 & 3 & 0 & 1 & 5 & $1 i$ \\
\hline
\end{tabular}

- Isolamento de mi coplasmas e produtos de concepçẫo no grupo de risco com alterações clinicamente definidas e no grupo sem alterações. 
TABELA VI

Relação entre as anomalias clínicas e

presença de micoplasmas no trato genital das gestantes

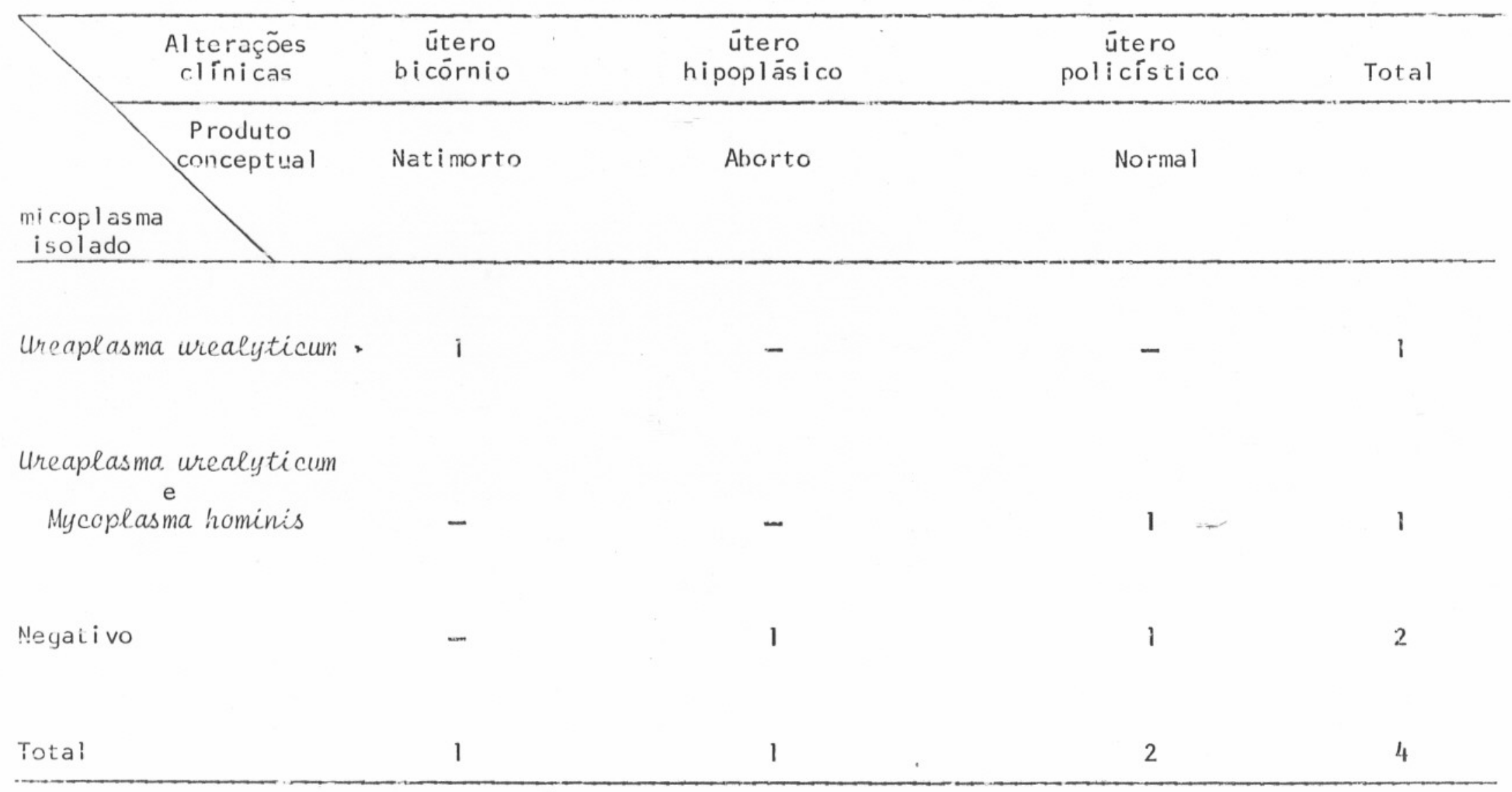

- Fornecidos dados de pacientes com al terações clínicas. 


\section{TABELA VII}

Relação entre micoplasma isolado da mãe e produto da concepção

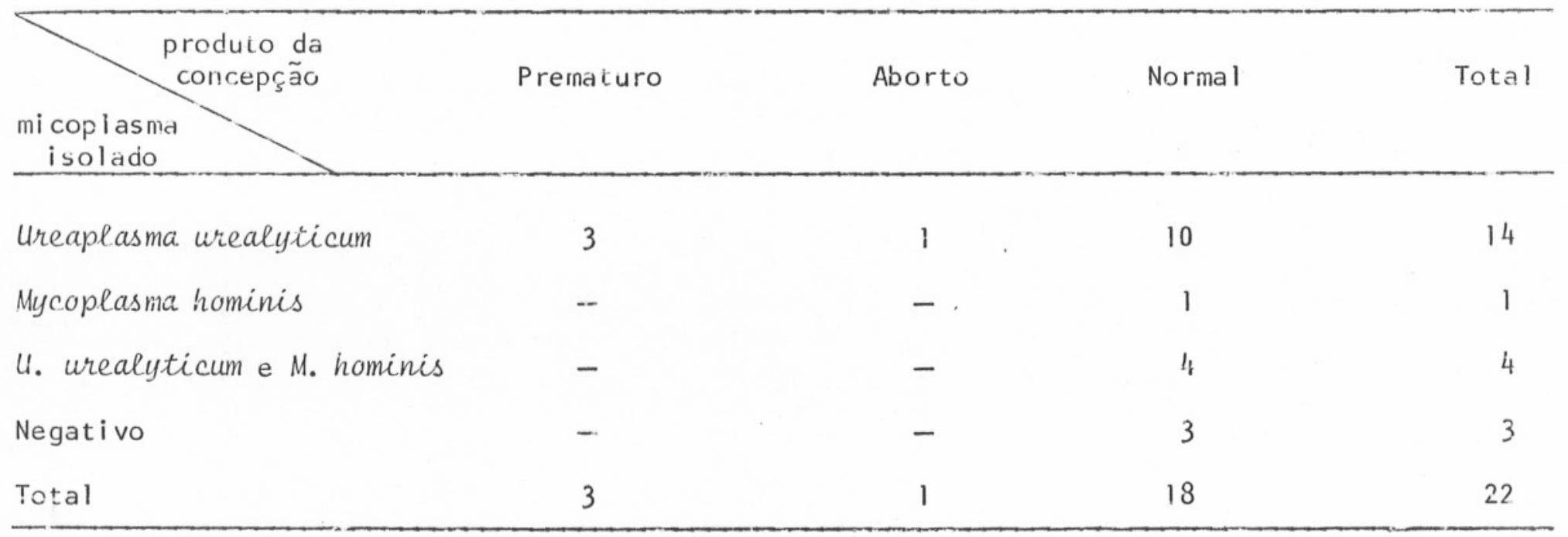

Esta tabela permi te observar a relação entre os micoplasmas isolados e as alterações ocorridas no produto conceptual. 
ceptual. De vinte e duas pacientes do grupo de risco que

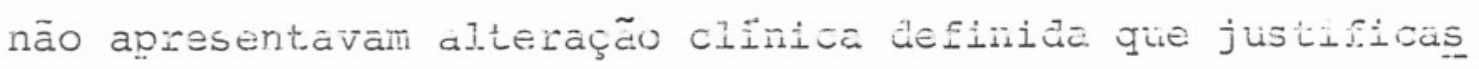
se as anomalias conceptuais, Ureaplasma urealyticum foi iso lado de três gestantes que tiveram prematuros, de uma que abortou e de dez que geraram crianças normais. A presença de Ureaplasma urealyticum e de Mycoplasma hominis, simulta neamente, foi verificada em quatro casos de nascimentos nor mais. Em três gestantes a pesquisa de micoplasmas resultou negativa e os produtos conceptuais foram normais.

\section{6 - Relação entre a presença de Trichomonas sp e micoplasmas}

Ainda foi possivel obter resultados adi-cionais quanto à presença de Trichomonas sp observada no exame direto do conteüdo vaginal dás gestantes com culturas positivas pạ ra Ureaplasma urealyticum elou Mycoplasma hominis.

O estudo de sua prevalência está expresso na tabela VIII.

Portanio, nas 74 (setenta e quatro) gestantes estudadas, a relaçäo entre a presença de micoplasmas e a incidên cia de Trichomonas $\mathrm{sp}$ foi a seguinte: em cinqthenta e três gestantes em que micoplasmas foram isolados, Trichomonas sp estava presente em onze. Dentre as vinte e uma gestantes em que a presença de micoplasmas foi regativa, três eram por tadoras de Trichomonas sp. Portanto, dos quatorze casos de 
tricomoníase onze estavam associados com micoplasmas. Por oulro Iado, do tolal üe sessenta casos negativos para a pre sença de Trichomonas sp, quarenta e dois eram positivos pa ra a pesquisa de micoplasmas.

Com a finalidade de avaliar se existe ou não uma cor relação entre a presença de Trichomonas sp e a positividą de de isclamento de micoplasmas, apjicou-se o teste estatis tico de comparação de duas proporções; considerando-se um

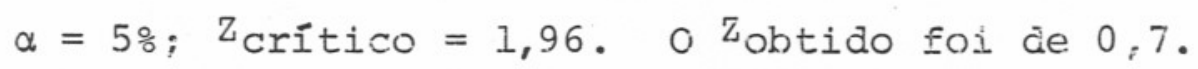

Sendo ${ }_{\text {critico }}>\mathrm{Z}_{\text {obtido, a diferença entre a propor }}$ ção de pacientes com Trichomonas sp que possuíam cuitura po sitiva e cultura negativa para micoplasmas, não é significante.

As colorações de Gram e Gienwa, para o rastreamento da presença de micoplasmas nas amostras clínicas, permitiram apenas sugerir uma provāvel presença dos mesmos.

TABELA VIII

Relação entre a presença de micoplasmas e a a incidēncià de Trichomonas sp

Trichomonas

micoplasmas

Presente Ausente Total

$\begin{array}{lrrr}\text { POSITIVO } & 11(20,8 \%) & 42(79,2 \%) & 53 \\ \text { NEGATIVO } & 3(14,3 \%) & 18(85,7 \%) & 21 \\ \text { TOTAL } & 14(18,9 \%) & 60(8 \mathrm{i}, 1 \%) & 74\end{array}$




\section{4 - DISCUSSÃO}

o isoíamento e a identificação de Mycoplasma hominis e de lireaplasma urealyticum em material de gestan tes, tem a sua significância calcada nas alterações clinnicas do trato geniturinário, de acordo com os vārios trabą lhos da literatura internacional $28,73,74,90$.

No Brasil, são poucas as referēncias sobre 0 estudo do significado clírico da presença dos micoplasmas genitais, bem como sobre as tëcnicas de cultivo e identifi cação dos mesmos.

A importāncia da colorização por esses micror ganismos e as subsequentes alterações cilnicas causadas nas gestantes, reside no provável comprometimento fetal tantas vezes ressaltado e questionado $7,29,106,121$.

o material clinico utilizado foi colhido ra região cervical denominada fundo de saco de Douglas. Este sitio, de acordo con as observaçöes feitas por REHEWY 104 , em razäo de possuir um pH mais elevado que o pH do fluxo va ginal, facilisa a instalação de micoplasmas, os qusis se desenvolvem melhor em 개 próximo da neutralidacie. 
e coieta da amostra clínica, estas visaram minimizar os ris cos de contaminação e de perda cie viabiliáade ajos micopiaj mas.

Para a coleta foi utilizado "swab" alginata do neutro, o qual é atóxico para micoplasmas e cuja utilização é recomendada por CLYDE \& MC CORMACK ${ }^{20}$ em seus estudos sobre coleta e transporte de amostras clínicas para pesqui sa de micoplasmas. O "swab" de algodäo, utilizado por MAGA LHÃES ${ }^{82,83}$ em seus estuajos sobre micoplasmas, pode conter ācidos graxos em sua composição, os quais iribem algumas es pëcies de microrganismos entre os quais os micoplasmas.

Uma vez que a amostra clínica não pode ser se meada imediatamente após a coleta, o transporte foi feito no meio MITr, utilizanōo-se um banho de gelo com a finalidade de manter a viabilidade dos micoplasmas, conforme o pre conizado por CLYDE \& MC CORMACK ${ }^{20}$.

O exame bacterioscöpico do material clínico obtido com auxílio de "swaib foi realizado utilizando-se as colorações de Gram e Giemsa. Apesar da dificuldade na observação dos micoplasias na superfície das células epiteli ais das amostras, estes podem ser melhor evidenciados pela coloração de Giemsa, conforme salientado por RAZIN ${ }^{100}$.

Para se conseguir resultados satisfatórios no isolamento desses microrganismos, a etapa do estudo da padronização dos meios de transporte, crescimento e idertifi cação tornou-se imprescincível e relevantes pelas dificuldades tanto na obtenção cie determinados componentes dos meios 
näo encontrados no mercado intexno, como tainbëm rıo proces-so de elidiouaçäo dos mesmos. Inúmeras tentarivas àe isola mento àos micoplasmass foram efetuadas com insucesso durar-te o presente trabalho, atë chegar-se às modificaçöes finais como as aqui apresentadas no capítulo de material e mé todos

Dentre as modificações introduzidas ro meio líquido de transporte MLTr, a substituição de alburnina bovina 30\% pela fração de soro PPLO, teve como objetivos tor ná--io mais acessivel, uma vez que a albumina bovina onera sua elaboração, além de facilitar tecnicamente seu preparo, visto que a filtração de albumina, através de membranas Mi.llipore $0,2 \mu \mathrm{m}$, na referida concentração é bastante difícil.

A introdução de anfotericina B na concentra

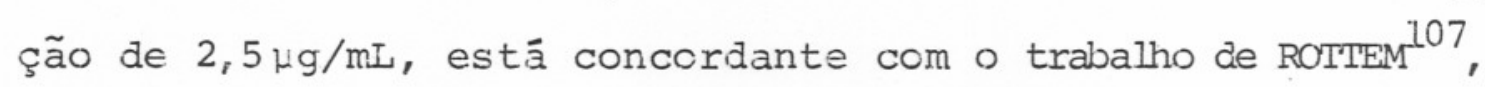
e foi feita com a finalidade de dificultar a proliferação de ieveduras nesse meic (MLiTr). Esta possui a capacidade de ligar-se a esteróis da memorana celular dos fungos aumentando-lhes a permeabilidade ceiular com perda de alguns de seus componentes intraceluiares essenciais. Apesar da anfoteracina B possuir uma maior arinidade pelo (esterol fúngi co), pode tambëm ligar-se ao colesterol da membrana dos mi coplasmas, jmpedindo assim seu crescimento. Por essa razão, concentraçöes maiores que $2,5 \mu \mathrm{g} / \mathrm{mL}$, como as preconizadas nos trabaihos de MATTHEWS ${ }^{86}$, MC CORMACK ${ }^{37}$ e ainda pelo Laboratory Diagnosis of Mycoplasma Infections ${ }^{231}$, não são recomendààas.

A penicilina G potássica foi adicionaca ao meio de transporte, originalmente descrito por SHEPARD ${ }^{114}$ : 
com a finalidade de servir como impediente aos microrganis mos äa tiora contaninante, a ela sensiveis.

No mejo líguido MLU, utilizado para o cresci mento de ureaplasma urealyticum, a substituição do componente de enriquecimento CVA(Gibco Diagnostics Madison, USA), da forma original descrita por SHEFARD, pelo VX(Bacto suplement VX, Difco Laboratories, Detroit Michigan, USA), foi feita dac̀a a facilidade de aquisição deste ültimo, além de que há hoje para comercializaçäo o suplemento vx de proce dência nacional (Suplemento VX LB, Laborclin, Paranā).

No meio MLA, para cultivo de micoplasmas ge nitais que hidrolizam a arginina, suprimiu-se a polimixina, a anfotericina $B \in$ a eritromicina do meio preconizado pelo Laboratory Diagnosis of Mycoplasma ${ }^{131}$, a fim de garantir o bom crescimento dos micoplasmas em questão, uma vez que tais substâncias, por seus efeitos impedientes sobre vārios microrganismos, poderiam também inibi-los parcialmente.A su-pressão das substâncias em questão, foi sustentada pela for mulação do meio de HAYFLICK ${ }^{59}$, meio bäsico para cultivo de micoplasmas clâssicos, da qual tais impeãientes não fazem parte.

No que se refere ao meio sólido utilizado pa ra a determinação da atividade da fosfatase, o emprego do p-nitrofenilfosfato como substrato alternativo, er substituiçäo à fenoftaleina difosfato de sölio, substrato de ele çä.o preconizačo por BERGEY 102 e por ALLUOmo ${ }^{2}$, foi devido a. impossibilidade da obtenção do mesmo. A hidrólise do p-ni trofenilf:osfało pela fosfatase dá origem, em meto aícalino, 
ao p-nitrofenol, composto que apresenta cor amarela. Da mes

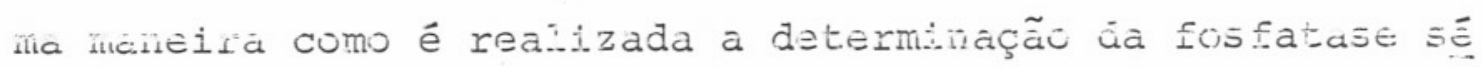
rica, adicjonou-se, apös o período de incubaçäo, hidróxiclo de sódio $0,02 \mathrm{~N}$ com a finalidade de parar a reação e alcalí nizar o meio, ressaltando com isso a cor do o-nitrofenol ${ }^{91}$.

O meio sölido utilizado para a detecção do fenōmeno da formação de filmes e "spots", foi preparado sü primindo-se do meio original os seguintes componentes:a so Iução de DNA a $0,02 \%$, o acetato de tálio e a penicilina G potássica. A supressão do DNA não acarretou prejuízos no desenvolvimento normal dos micoplasmas, o que foi constatâ do atravēs do uso de controle positivo nas mesmas condições da semeadura e incubação.

Quanto ao emprego do acetato de tälio e da penicilina, usualmente utilizados como impedientes da florà contamjinante, não se fez hecessário umà vez que os mico plasmas testados encontravam-se puros. O efieito inibitörio produzido pelo acetato de tálio sobre as cepas de Ureaplasma urealyticum, foł tambēm uma das razões da sua não utilização ${ }^{131}$.

Na classificação dos mi.crorganismos isolados como membros pertencentes à família Mycoplasmctaceae, a ne cessidade de colesterol é vista como um dos critērios mais importantes ${ }^{103}$. Para tanto, a prova de sensibilidade à di gitonina $1,5 \%$, realizaàa de acordo com a tëcnica descrita por FREUNDT 45 , permitiu considerar todos os microrganismos testados como nutricionalmente exigentes desse componente, uma vez que os diāmetros de inibição obtidos por nossos 
isolados foram iguais ou superiores a $5 \mathrm{~mm}$.

Caracterizaç̃o dos gêneros Mycoplasma e Ureaplasma

A caracterização dos genêros Mycoplasma e Ureaplasma foi baseada na morfologia colonial caracteristi ca no neio MSM, no comportamento bioquímico que possibilitou a identificaçäo da espécie Ureaplasma urealyticum,e na identificação sorolōgica com soro imune específico atravēs dos testes de inibição metabólica e imunodifusão dupla, os quais permitiram a identificação de Mycoplasma hominis.

lireaplasma urealyticum pode ser identificado bioquimicamente por possuir a capacidade de hidrolizar a urëia atravēs da enzima urease, com produção de amônia, cạ racteristica única entre os Mollicutes ${ }^{116}$.

Esta ativiaace foi detectada de acordo com a metodologia descrita por RAZIN ${ }^{201}$, através da observação de colônias diminutas marrom dourado, cuja coloraçäo é decorrente da produção de $\mathrm{MnO}_{2}$ em presença de amônia. Não foi possivel realizar a identificação soroló̧ica para diferien ciar os diferentes sorotipos, mas a pröpria literatura re gistra alguns trabalhos como os de DISCHE ${ }^{28}$ FOY $^{40} ;$ BIDET $^{5}$; TARAFI 124 e MAGALHÃES ${ }^{82}$, os quais identificaram o Ureaplasma urealyticum baseados na morfologia colonial e na atividade da urease.

Quanto às conciçöes de incubação em diversas etapas de semeadura e de i.dentificação do mícrorganismo, vạ 
rios autores preconizaram a anaerobiose à 37oc como serdo a ideal. $39,83,84$. Todavia, observando-se ns efeitos dac in cubações à 37̣̣c, em aerobiose, microaerofillìa (jarra com ve la), e anaerobiose, sobre o crescimento, constatou-se no presente estudo que tarto a microaerofilia quanto a ariaero biose propictavam o mesmo resultado. Desta forma, optou-se pela microaerofilia, uma vez que para obter-se condições de anaerobiose seria necessário o emprego do sistema GasPack. (BBI), o qual é bastante oneroso.

Todos os isolados foram submetidos a prova da urease, mas os resultados foram positivos somente para os icentificados como Ureaplasma urealyticum, demonstrando a fidelidade da mesma.

A diferenciação presuntiva entre as espécies co gênero Mycoplasma foi realizada com o auxilio de algumas provas bioquímicas, uma vez que todas elas apresentam morfologia colonial semelhante ${ }^{102}$.

Como integrante do grupo de micoplasmas cujo crescimento ë estimulado pela arginina, o Mycoplasma hominis apresenta como provävel m.ecanismo para a degradação deste aminoācido, a via arginina deidrolase. Alēm do Mycoplasma hominis podem ser citados como pertencentes a este crupo o Mycoplasma bucalle, o Mycoplasma bermentans, o Mycoplasma orale e o Mycoplasma salivarium que, embora muito raramen te, podem eventualmente ser encontrados no trato geniturinārio.

A distinção das espēcies M. hominis e M. orale. 
foi bioquimicamente impossível, uma vez que anbos são negą tivos às provas äe metabulismo dà glicose, à a.tividade da fosfatase, à formação de filmes e "spots" e à redução do tee trazólio em aerobiose e em anaerobiose.

As pjoovas de inibição retabólica e de imuno difusão dupla possibilitaram a identificaçăo final do Mycoplasma hominis. As duas provas foram concordantes, mito embora, quan do da realização da inibição metabólica encontrou-se certa dificuldade na visualjzação da mudança da cor do meio de corrente da alteração do pï. As maiores dificuldades resi diram portanto na faixa de variação do $\mathrm{pH}$ do indicador (ver melho de fenol), de 6,8 para 7.6-7,8, e na utilização da microtécnica a qual não fornecia bons contrastes entre a cor original do meio e a cor da reação positiva.

Caracterizados os micoplasmas obtidos do cul tivo das amostras clínicas, estudou-se a prevalência desses microrganismos no grupo de risco e no grupo de controle.

A proporção de micoplasmas isolados nopresen te estudo foi de $94,6 \%$ no grupo de risco e de $81,2 \%$ no gru po de controle. As proporções de Ureaplasma urealyticum e de Mycoplasma hominis iscladas no total de gestantes estü dado foram de $69,0 \%$ e 19,0\%, respectivamente (Tabelal II). Tais resultados foram concordantes quando comparados com os de HARRISON ${ }^{56}$, realizado em Tucson nos Estados Unidos, e de MAJORI ${ }^{84}$, realizacio em Trieste, Itália, pois demonstraram a eficiência da netodologia utilizada, uma rez que os referi. dos autores, trabalhando com grupos e amostras clinjicas se 
melhantes, obtiveram: $72.3 \%$ de isolamento de lireaplasma urealyticum e 2.3,5\% de inycoplasma hominis, e 75,7\% de uiteuplusma urearyticum e 1i,7\% de Mycoplasma hominis, respectivamente.

No presente trabalho, do grupo de risco foi isolado Ureaplasma urealyticum de 21 pacientes $(56,8 \%)$, Mycoplasma hominis de dois $(5,4 \%) \in$ ambos foram encontra dos simultaneamente em seis pacientes $(16,2 \%)$.

No grupo controle, Ureaplasma urealyticum foi encontrado em 18 pacientes $(48,6 \%)$, Mycoplasma hominis iso ladamente não foi encontrado em nenhuma $(0,0 \%)$, enquanto que a presença simultânea de Ureaplasma urealyticum e Mucoplasma hominis foi observada em seis casos (16,2\%) (Tabela II). Foi aincảa verificada uma taxa de $29,7 \%$ de gestações terminadas anormalmente no grupo de risco, enquanto que no grupo con trole neniurn caso semelhante foi observado.

Esses resultados diferem daqueles encontrados por KUNDSIN e DRISCOLL ${ }^{73}$ que, utilizando o mesmo tipo de mä terial clínico (inaterial cervical), e meios de cultivo análogos aos utilizados no presente estudo (meio básico de HAYFLICK ${ }^{59}$ para micoplasmas clássicos $\epsilon$ meio de SHEPAR.D 113 para cepa $T)$, encontrararn $67 \%$ de positividade para micoplas mas no grupo de risco e $48 \%$ no grupo controle. Desse total, Ureaplasma urealyticum (cepa T) foi isolado em 42,5\% dos ca sos, Nycoplasma hominis em somente $i, 8 \%$ dos casos e o encon tro simultâneo de ambos fo: verificado en $22 \%$ das pacientes do grupo de risco. No grupo controle, os resultados foram: em $2 \varepsilon, 0 \%$ das pacientes foi isolado ureaplasma urealyticum, enquanto que Mycoplasma hominis foi encontrado em 6,0\% e am 
bos foram isoíados simultaneamente em 14,0\%. Äém disso os autcres verificaram que 12,00 daz gataçöes do grupo de ris co e 23,0\% daquelas do grupo controle terminaram anormalmente. Diante desses resultados, sugeriram um provável en volvimento dos micoplasmas como patögenos nos casos de ges tações anormais.

No presente trabalho, contudo, não foi possi vel inferir nada a respeito da patogenicidade desses micror ganismos, uma vez que as taxas de incidência nos grupos de risco e controle não foram estatisticamente significantes. Apesar de não sexem significativas as diferenças na prevalência entre os dois grupos, foi possível ob servar que, entre as 37 pacientes do grupo de risco (Tabe la III), 15 possuíam alterações definidas clinicamente e que justificavam as anomalias gestacicnais; dessas, sote tive ram gestações terminadas anormalmente, sencoo cinco com cul turas positivas para micoplasmas. Dentre as oito restantes, cujo produto conceptual foi normal, cinco tiveram cultura positiva para micoplasmas. Das outras 22 gestantes do gru po de risco, as quais não possuiam qualquer indício clínico que justificasse os insucessos gestacionais, quatro tive ram suas gestações terminadas de modo anormal, tendo todas cultura positiva. Dentre as 18 restantes deste grupo, cujos produtos conceptuais foram normais, 15 eram positivas para micoplasmas. Esses achados sugerem a necessidade de estudos posteriores sobre a problemárica enfocada, para que se pos sa chegar a um resultado mais consistente e conclusivo. 
Um outro dado também controvertido e aqui en focado foi guanto à possível relução existonto cntro a pre senças de Ureaplasma urealyticum $\in$ a de Trichomonas sp. REHEWEY ${ }^{104}$, estudando a presença de ll.reaplasma ureafyticum no fluido vaginal e no muco cervical, verificou que de am bos os materiais clínicos não se isclava Ureaplasma urealyticum quando Trichomonas sp estava presente. Ele concluiu que pro vavelmente alguns dos subprodutos produzidos pelos tricho monas tornavam desfavorável a instalação de ureaplasmas. GIACOMINI ${ }^{52}$ contudo, ao contrário de REHEWEY, encontrou uma associação entre a presença, de tricomonas e o isolamento de Ureaplasma urealyticum, justificando assim o caraácter oportunista dos micoplasmas. Este autor constatou que nor malmente em gestantes jā havia um decréscimo na incidência de tricomonas, em decorrência provavelmente das alterações de mucosa observadas durante a gestação.

No presente estudo, o Ureaplasma urealyticum foi encontrado independentemente da presença ou não de tri chomonas, e a inexistência de associação entre os dois agen tes foi confirmada estatisticamente conforme dados expostos no capitulo Resultados.

o presente trabalho, realizado em condições que nosso meio permitiu, revelou ser possível o isolamento e a identificação de micoplasinas atravēs da netodologia aqui descrita, acessível ao l.aboratório de rotina diagnóstica.

Quanto à irterpretação clínica da presença de micopiasmas e as alterações gestacionais nada pode ser estabelecido, una ver que a prōpria controvérsia existente 
na literaturd internacional, aeronstra a grande dificulda de em se atribuir um papel putogênico para esses microrga nismos sobretudo nas alterą̧ões maternofetais.

Se as pesquisas fossem voltadas para a sorctipagem das cepas isoladas de Ureaplasma urealyticum e de Mycoplasma hominis poderiam talvez elucidar alguns aspectos ainda obscuros. IIN ${ }^{80}$, nos Estados Unidos da América, em seus estucios sorológicos sobre micoplasmas genitais humanos, verificou a presença de mais de um sorotipo de Ureaplasma urealyticum em uma ünica amostra clínj.ca. KAPUR ${ }^{66}$, desenvol vendo na Inaia um trabalho de isolamento de T-mycoplasmas de secreção uretral, tambëm pressupôs, devido às variações entre sintomatologia clínica e o isolamento de micopiasmas, haver cepas de T-mycoplasmas com diferentes graus de virulência. E finalmente, QUINN, com seus estudos realizados em Toronto no Canadá, sobre evidência sorológica do Ureaplasma urealyticum nas infecções em mulheres com histórico de abor to espontâneo 98 , observou que, de acordo com seus resuita dos, certos sorotipos de Ureaplasma urealyticum poderiam ser mais patogênicos do que outros.

Ein vista do fato de que no nosso meio pouquís simos invetigadores dedicam-se ao estudo dos micoplasmas, é intenção nossa prosseguir as pesquisas deste microrgarís mo, abordando melhor os aspectos antigëniccs e imunogênicos, contriblíndo para a determinação de sorotipos, com o in tuito de fornecer subsidios ao diagnóstico dessa infecção, alēm da verificaçăo do estado de imunidade clas gestantes. 


\section{5 - RESUMO E CONCLUSÕES}

Alicerçado em trabalhos contidos na literatul ra internacional sobre a implicação dos micoplasmas nas al terações do trato geniturinário e sobretudo nas chamadas "falhas da reprodução", o presente estucio teve como objeti vo, alëm da introdução de uma tecnologia de pesquisa desses microrganismos acessível ao laboratório clínico de ro tina dìagnóstica, também determinar as taxas de colonizaÇäc de Mýcoplasma hominis e de Ureaplasma urealyticum em gestantes pertencentes a uma classe de baixo nível söcio-econômico.

Estas gestantes, em número de 74 (setenta e quatro), foram divididas em dois grupos: um grupo de 37 (trinta e sete) gestantes que possuía histórico anterior de alteraçöes perigestacionais colno: abortos, natimortos, pre maturos, etc., e que constituíram o Grupo de Risco; e o cuㅡ tro constituído de 37 (trinta e sete) gestantes com gestatações anteriores normais, Grupo Controle.

Utilizando-se os materiais e mētodos adapta dos às condições de nosso meio, foram encontrados os seguin tes resultados: a proporçäo de micoplasmas isolacia fici de $94,6 \%$ ro grupo de riscc $\in$ de $81,2 \%$ no grupo controie. Do 
grupo de risco, Ureaplasma wreatyticum foi isolado de vi.nte e um pacientes $(56,35)$, Rijoupiusma nominis de dois $(5,4 \%)$

e ambos foram encontrados em seis pacientes $(16,2 \%)$. No grupo controle, lireaplasma urealyticum foi encontrado em 18 pacientes $(48,6 \%)$, Mycoplasma hominis não foi isclado de ne nhuma $(0,0 \%)$, enquanto que a associação Ureaplasma urealyticum e Mycoplasma hominis foi observado em seis casos $(16,2 \%)$. Foi ainda verificado que onze $(30,5 \%)$ gestações terminaram anormalmente no grupo de risco, sendo quatro $(11,1 \%)$ de pa cientes que não possuíam quaisquer alterações clínicas que as justificassem. No grupo controle, nenhuma alteração foi verificada entre os casos notificados.

A análise estatística, dos resultados, permi tiu verificar que näo houve diferenças significantes entre os grupos estudados.

\section{CONCLUSÖES}

- As modificações introduzidas nos meios de cultivo empregaāos no transporte, isolamento e marutençäo das cepas, fornecerain resultados satisfatčrios.

- A metodologia utilizada possibilitou a identificação dos micoplasmas, sobretudo do Mucoplasma hominis, cuja caracterização final foi rea.lizada através de tēcnicas soroló gicas. 
- A proporção de isoíainenco de micoplasmas no total de ges sartes estudacios foi de $87,8 \%$, sendo $68,9 \%$ do lheaplaska urealyĩicum e 18,98 de Mycoplcsma hominis, proporções es tas comparáveis cor. as encontradas na literatura interna cional.

- As taxas de isolamento de Ureaplasma urealyticum e de Mycoplasmas hominis no arupo de risco foram de $73,0 \%$ e $21,6 z$, respectivamente. No grupo controle as taxas obti das foram de $65,0 \%$ de ureaplasma urealyticum e de 16,2\% de Mycoplasma hominis. Apesar da proporção de positivos ser mais baixa no grupo controle do que no grupo de risco, as diferenças não foram estatisticamente significantes.

- Não se constatou associação entre a presença de Trichomonas sp e de Ureaplasma urealyticum no trato genital de gestantes. 


\section{REFERENCIAS BIBLIOGRAFICAS *}

1. ALTOMAPE, G.F.; POLENGHI, M.M.; PIGATTO, P.D.; BELLA, G.; VIVANTI, R.; ITALIANO, P. - The role of mycoplasmas in sexually transmitted vaginitis. Boll. Ist. Sieroter. Milan., Milan, 63(4):348-51, 1984 .

2. ALUOTTO, B.B.; WITTLER, R.G.; WILLIANS, C.O.; FABER, J.E. - Standardized bacteriologic techniques for the characterization of Mycoplasma species. Int. I. Syst. Bacteriol., washington, 20:35-58, 1970.

3. BARILE, M.F.; SCHIMKE, R.T.; RIGGS, D.B.-- Presence of the arginine ähydrolase pathway in Mycoplasma. J. Bacteriol. , Baltimore, gl(1):189-92, 1966.

4. BENNETT, A.H.; KUNDSIN; R.B.; SHAPIRO, S.R. - T-strain mycoplasmas, the etiologic agent of non-specific urethritis: a venereal disease. J. Urol., Baltimore,

* De acordo com as normas preconizadas pela ASSOCIAÇÃo BRA SILEIRA IF NORMAS TECNICAS (ABNM). As abreviaturas e local de publicação dos periódicos seguem o CHEMICAL FBSTRACr's SERVICE SOURCE INDEX (CASSI), 1984. 
$109: 427-9,1973$.

5. BIDET, F. \& MINCK, R. - - Recherche de mycoolasmes T' chez les accouchëes. Nouv. Presse Med., Paris, I $(10): 851,1978$.

6. BØE, O.; IVERSEN, O.E.; NEHL, A. - Septicemia due to Mycoplasma hominis. Scand. J. Infect. Dis., Stodtholm, $\underline{15}(1): 87-90,1983$.

7. BONISSOL, C. ; BOUSQUET, C.; DURIUX, M.F. - Contribution a l'ētude des souches i de Mycoplasmes dans les infeccions vaginales et uretrales. Pathol. Biol., Paris, 20:909-18, 1972 .

8. BORDET, J. - La morphologie du microbe de la përipneumonie des bovidés. Ann. Inst. Fasteur, Faris, 24: 161-7, 1910.

9. BORREL; DUJARDIN-BEAUMETZ; JEANTET; JOUAN. - Le microbe de la pēripneumonie. 쓰n. Inst. Pasteur, Paris, 24 : $168-79,1910$.

10. EOWIE, W.R. - Etiology of nongonococcal urethritis, evidence for chlamydia trachomatis and Ureaplasma lire alyticum. J. Clin. Invest., New York, 59:735-42, 1.977.

11. BREDT, W.; EELDNER, J.; KAHANE, I, - Adherence of mYYcoplasmas to $a \in l . l s$ and inert surfaces: phenomena, experimental models and possible mechanisms. Is.. 
J. Med. Scì., Jerusälém, 177:585-8, 1981.

12. BRIDE, J. \& DONATIEN, A. - La microbe de lägalaxie con tagieuse du mouton et de la chèvre. Ann. Inst. Pasteur, Paris, 39:925-51, 1925 .

13. BRUNNER, H.; WEIDNER, W.; Schiefer, H.G. - Studies on the role of Lreaplasma urealyticum and Mycoplasma hominis in prostatitis. J. Infect. Dis., Chicago, v.147(5): 807-13, 1983 .

14. BUSOLO, F.; Zanchetta, R. - Do mycoplasmas inhibit the human sperm fertiling ability in vitro? Isr. J. Med. Sci., Jerusalēm, 20:902-4, 1984 .

15. CASPI, E.; SOLOMON, F.; SOMPOLINSKY, D.B.V.M. - EarIY abortion and Mycoplasma infection. Isr. J. Med.

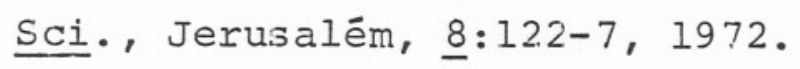

16. CHFNOCK, R.M.: DIENES, L.; EATON, M.D. ; ELWARD, D.G.ff ; FPELNDT, E.A; HAYFLICK, L.; HERS, J.E; JENSEN, K.E.; LIU, C.; MARMION, B.P.; MORTON, H.E.; MUESON, M.A.; SMITH, P.F.; SOIERSON, N.L.; TAYLOR-RCBINSON, D. -Mycoplasma pneumoniae: Proposed nomenclature for atypical pneumonia orçanism (Eaton Agent). Science., Washington, 140:662, 1963.

17. CHANOCK, R.M.; HAYFLICK, L.; BARILENE, M.F. - Growth on artificial medium of an agent assocjated with 
atypical pneumonia and its identification as a PPLO. Proc. Natl. Acaa. Sci. USA, Washinçtor, 48:41-9, 1962.

18. CHRISTENSEN, K.K.; HAGERSTRAND, I:; MARDH, P. - Late spontaneous abortion associated with Myccplasma hominis Infection of the fetus. Scand. J. Infect. Dis., Stockolm, 14(1):73-4, 1982 .

19. CLYDE, W.A. MYcoplasma-animal host interelationships. In: RAZIN, S. \& TULIY, J.G., eds. Methods in mycoplasmology. New York, Academic Eress, 1983. v.1, p. 15-9.

20. CLYDE, W.A. \& MCCORMACK, W.M. - Collection and transport of specimens. In: RAZIN, S. \& TULLY, J.G.,eds. Methods in mycoplasmology. New York, Academic Press, 1983. v.l, p.103-7.

21. COSTA NETO, P.I.O. - Estatística. São Paulo, Edgard Blthcher, 1977. p.118-9.

22. DARJAND, G.; BROCK, T.D.; SAMSONOFF, W.; CONTI, S.F. A. thermophilic, acidophilic, mycoplasma isolated from a coal refuse pile. Science, Washington, 170: $1416-8,1970$.

23. DIENES, I. - Cultivation of pleuropneumonia-like orga nisms from female genital organs. Proc. Soc. Exo. Bioi. Med., New York, 44:468-9, 1940. 
24. DIENES, L. - Euxther Observations on the I-organism of klieneherger. Proc. Soc. Exp. Biol. Nied. "New Yodk, $\underline{39}: 365-7,1938$.

25. DIENES, I. \& EDSAII, G. - Observations on the I-organism of Klieneberger. Proc. Soc. Exp. Biol. Med., New York, 36:740-4, 1937 .

26. DIENES, L. \& SULIIVAN, E.R. - Morphology and Nature of Pleuropneumonia-Like Microbrganisms. Proc. Soc. Exp. Biol. Med., New York, 41:424-6, 1939.

27. DIMUSTO, J.C.; BOHJALIAN, O.; MILLAR, M. - Mycoplasma hominis type I infection and pregnancy. Obst. Gynecol., Amsterdan, 41:33-7, 1973.

28. DISCHE, M.R.; QUINN, P.A.; CZEGLEDY-NAGY, E.; STURGESS, J.M. - Genitai mycoplasma infection intrauterine infection: pathologic study of the fetus and placenta. Am. J. Clinn. Pathol., Philadelphi.a, 72:167$74,1979$.

29. DRISCOLL, S.G.; KUNDSIN, R.B.; HORNE, H.N.; SCOTT, J. M. - Infections and first trimester losses: possible role of mycoplasmas. Fertil. Steril., Birmingham, 201 $: 1017-9,1969$.

30. EDNARD, D.G.ff. - Determination of sterol requeriment for mycoplasmatales. J. Gen. Microbiol., Colchester, 
$69: 205-10,1971$.

31. EDVARD, D.G.ff. -- An investigation of the biological properties of organisms of The pieuropneumonia group, with suggestions regarding the identification of strains. I. Gen. Microbiol., Colchester, $\underline{4}$ : $311-$ 29, 1950 .

32. EDWARD, D.G.ff. - A Suggested classification and nomen clature of organisms of the pleuropneumonia group. Int. BuIl. Bacteriol. Nomencl. Taxon., Ames, $\underline{5}(2)$ : $85-93,1955$.

33. EDWARD, D.G.ff. - The pleuropneumonia group of organisms: a review, together with some new observations. J. Gen. Microbiol., Colchester, 10:27-64, 1954.

34. EDWARD, D.G.ff.\& FREUNDT, E.A. - Amended nomenclature for strains related to Mycoplasma laidlawii. I. Gen. Microbiol., Colchester, 62:1-2, 1970.

35. EDWARD, D.G.Ef. \& FREUNDT, E.A. - The classification and nomenclature of organisms of the pleuropneumonia group. J. Cen. Microbiol., Colchester, 14:197-207, 1956 .

36. EDWAKD, D.G.ff. \& FREUNDT', E.A.-- Proposal Eor Nollicutes as rame of the class established for the orde: 
Mycoplasmatales. Int. J. Syst. Bacteriol., Washington, İ(3): $25 \%-\bar{\delta}, \quad 190 \%$

37. EMBREE, J.E.; KFLISEER, V.W.; EMBII, U. A. ; MACDONALD, s. - Placental infection with Mycoplasma hominis and Ureaplasma urealuticum: clinical correlation. Obstet. Gynecol., New York, 56(4):475-81, 1980.

38. FOSTER, J.P. - Some historical notes on contagious Pleuro-Fneumonia. J.Am. Vet. Mec. Assoc., Chicago, $1: 918-22, \quad 1934$.

39. FOY, H.; KENNY, G.E.; LEVINSOHN, E.M.; GRAYSTON, J.T. Acquisition of mycoplasmata and $\mathrm{T}$ - Strains during infancy. J. Infect. Dis., Chicago, 12I(6):579-86, 1970 .

4!. FOY, H.; KENNY, G.; BOR, E.; HAMMAR, S.; HICKMAN, R.Prevalence of Mycoplasma hominis and Ureaplasma urealyticum ( $T$ strains; in urine of adolescents. J.Clin. Microbiol. : Washington, 2(3):226-30, 1975-

41. FOWLKES, D.M.; DOOHER, G.B.; OLEARY, W.M. - Evidence by scaning electron microscopy for an association between spermatozoa and T- mycoplasmas in men of infertile marriace. Eertil. Sieril., Birmingham, 26: $: 12): 1.203-11,1.975$.

42. FREUNDT, E.A. - The classification of the pieuropneu- 
monta group of organisms (Borrelomycetales). Int. Bul1. Bacteriol. Nomenci. Tason., 3i2j:57-70, i5j5.

43. FREUNDT, E.A. - Culture Media for Classic Niy coplasmas In: RAZIN, S. \& TULLY, J.G., eds. Methods in mycop.lasmology. New York, Facademic Press, 1983. v.1, p. 128 .

44. FREUNDT, E.A. - Film and spot production. In:RAZIN, S. \& TULIY, J.G., eds. Methods in mycoplasmology. New York, Academic Press, 1983. v.1, p.373-4.

45. FREUNDT, E.A. -Mycoplasma hominis: historical outline and taxonomy, Sex. Trans. Dis., Philadelphia, 10 (4 supl.):226-9, 1983.

46. FREUINDT, E.A.; ANDREWS, B.E.; ERNO, H.; KUNZE, M.; BLACK, F.T. - The Sensitivity of Mycoplasmatales to Studium -Polynethol-Sulfonate and Digitonin. Zentralbl. Bakteriol. Midroblol. Hyg. Abt.1 Drig.A. 222:104-12, 1973.

47. FREUNDI, E.A. \& EDWARD, D.G.ff. - Classification and Taxonorny. In:BARILE. M,F. \& RAZIN, S., eds. The mycopiasmas. New york, Academic Press, 1979. v.1, p. 24 .

48. FREUNDT, E.A. \& EDWARD, D.g.ff. — Proposal for establishing a new genus (A.choleplasma) and family 
(Acholeplasmataceae) of the order Mycoplasmatales. Int. J. Syst. Dactericl. , Weshington, 21:151-3, 1971.

49. FRIBERG, J. - Mycoplasmas and ureaplasnias in infertility and aboxtion. Fertil. Steril., Birningham, 33(4): $351-9,1980$.

50. FRIBERG, J. \& GNARPE, H. - Mycoplasma and human repro ductive failure III. Pregnancies in "infertile" couples. Am. J. Obstet. Gynecol., St. Louis, I:23$6,1973$.

51. GELMANN, A.C. \& DERS HEWITZ, D. - Skene's gland infection. J. Urol., Baltimore, 135:786-8, 1986.

52. GIACOMINI, T.; DUMOUCHEI, P.; LOCKNER, M.; BARDIAUX, M. - Recherche Systeématique d'Ureaplasma urealyticum au cours des prëlèvements vaginaux. Fésultats. J. Gynecol. Obstret. Biol. Reprod., Paris, 9:439-43, 1980.

53. GNARPE, H. \& FRIBERG, J. -- Mycoplasma and human re productive failure. I. The occurrence of difecrent mycoplasmas in couples with reproductive failure. Am. I. Obstet. Gynecol.., St.Louis, 15:727-31, 1972.

54. GNARPE, H. \& FRIBERG, J.- T-Mycoplasmas on Spermatozoa and infertility. Nature., London, 245(5420):97-8, 2973. 
55. GRANT, C.L. \& PRANER, D. - Minor element composition of yeast extract. I. Bacteriol.. Baltimore, 84:869$70,1962$.

56. HARRISON, H.R.; AIEXANDER, E.R. ; WEINSTEIN, L.; LEWIS, M.; NASH, M.; SIM, D.A.-- Cervical Chlamydia trachomatis and mycoplasmal infections in pregnancy. JAMA J. Am. Med. Assoc., Chicago, 250(13):1721-7, 1983.

57. HARWICK, H.J.; PURCELI, R.H.; IUPPA, J.B.; FEKEIY, F. R. - Mycoplasma hominis and abortion. J. Infect. Dis., Chicago, 121:260-8, 1960 .

58. HARWICK, H.J.; PURCELI, R.H.; IUPPA, J.B.; FEKETY, F. R. - Mycoplasma hominis anc pospartum febrile compli cations. Obstet. Gynecol., New York, 37: 765-8, 1971.

59. HAYFLICK, L. \& CHANOCK, R.- Mycoplasmas species of man, Bacteriol. Rev., 29 (2):185-2.21, 1965.

60. International Committee on Bacteriological Nomenclatụ re. The status and synonymy of the bacterial generic name ASTEROCOCCUS. Int. Bull. Bacteriol. Nomencl. Tax Ames, $\underline{5}(1): 13-20,1955$.

61. International Committee on Systematic Bacteriology. Subcommittee on the Taxonomy of Mollicutes. Propo sal of minimal standards for descriptions of new species of the class Mollicutes. Int. J. Syst. 
Eacteric.., Washingtor, 29:172-80, 1979 .

62. International Comittee on Systematic Bacteriology. Subcomittee on the Taxonomy of Mycoplasmatales. Proposal for minimal standards for descriptions of new species of the order Mycoplasmatales. Int. J. Syst. Bacteriol., Washington, 22(3):184-8, 1972.

63. JONES, D.M. - Mycoplasma hominis in abortion. Br. Med. J.. London, $1: 338-40,1967$.

64. JONES, D.M. - Mycoplasma hominis in pregnancy. J. Clin. Pathol., Iondon, 20:633-5, 1967.

65. KAHANE, I. - In vitro studies on the mecanism of adherence and pathogenj.city of mycoplasmas. - Isr. J. Med. Sci., Jerusalem, 20: $2074-7,1984$.

66. KAPUR, T.R.; SINGH, O.P.; GUPTA, Z.; HINGORANI, V. ; KANDHARI, K.C.; BHUTANI, L.K. - Isolation of T-mY coplasma (Ureaplasma urealyticum) from the genito-urinary tract. J. Indian Med. Assoc., Calcutta, $\underline{70}(5): 101-3,1978$.

67. KLIENEBERGER, E. - The colonial development of the organisms of Dleuropneumonia and agalactia on serum agar and variations of the morphology under different corditions of growth. J. Pathol. Bacteriol. Eäirburọt, 39- 39:409-20, 1934. 
68. KLIENEBERGER-NOBEL, E.- MYcoplasma, A Brief Historical Review. Prn. N. Y. Acad. Scil., New York, 143:713-8, 1.967 .

69. KIIENEBERGER, E. - The natural occlirrence of Pleuro pneumonia Like Organisms in apparent symbicsis with Sireptobaccleus moniliformis and other bacteria. J. Pathol. Bacteriol., Edinburgh, 40:93-105, i935.

70. KOSSMAN; J.C.; FLORET, D.; RENAULD H.; SEPETJIAN, M.: MONNET, P. - Syndrome de fiessinger jeroy reiter chez I'effant et Ureaplasma urealyticum (Mycoplasma Tiny). pédiatrie., Lyon, 35(3):237-42, 1980.

71. KUNDSIN, R.B.; AMPOLA, M.; STREETER; S.; NAURATH, P.Chromosomai aberrations induced by $\mathrm{T}$ strain Mycoplasmas. J. Med. Genet. London, 8:181-7, 1971.

72. KUNDSIN, R.B.; DRISCOLI, S.G.; MONSON, R.R. ; YEH, C. ; BIANO, S.A.; COCHRAN, W.D. - - Association of Ureaplasma urealyticum in the placenta with perina tal morbidity and mortaiity. N. Engl. J. Med., Boston, 310:941-5, 1984 .

73. KUNDSIN, R.B. \& DRISCOII, S.G. - Mycoplasma and human reproductive failure. Surg. Gynecol. Obstet., ChiCago, 131:39-92, 1970.

74. KUNDSIN; R.B.; DRISCOLL, S.G.; MING, P.M.L. - Strain 
of Mycoplasma associated with human reproductive Eailure. Science., Washington, 157:1573-4. 1967.

75. KUNDSIN, R.B.; DRISCOLL, S.G.; PELLETIER, P.A. Ureaplasma urealyticum incriminated in perinatal morbidity and mortality. Science., Washington, $\underline{21} \underline{3}$ $(4506): 474-5,1981$.

76. LAIDLAW,P.P.; F.R.S.; ELFORD, W.J. - A New Group of Filterable Organisms. Proc. Roy. Soc., Iondon B, 120: $292-303,1936$.

77. LAMEY, J.R. ; ESCHENBACH, D.A.; MITTCHELL, S.H.; BLUMHAGEN, J.M. ; FOY, H.M. ; KENNY, G.E. - Isolation of mycoplasmas and bacteria from the blood of postpartum women. Am. J. Obstet. Gynecol., St.Iouis, 143:10412,1982 .

78. LEDINGHAM, J.C.G. - The growth phases of pleuropneumonia and agalactia on liquid and solid media. J. Pathol. Bacteriol., Edinburgh, 37:393-409, 1933

79. I.MCKE, R.M. - A serological comparison of various species of mycoplasma by an agar gel double diffusion technique. J. Gen. Microbiol., colchester, 38:91100,1965 .

80. LIN, Z.S.L.; RADNAY, K.; KENDRTCK, M.T.; PCSNER, B.;KASS, E.H. Serologic studies of human genital mycoplasmas: 
distribution of titers of̈ mycoplasmacidal artibody to Ureablasma urealudicum and ilycopeasma hominis in pregnant women. I. Infect. Dis., Chicago, 137 (3): $266-72,1978=$

81. IOWRY, O.H.; ROSEBROÜGH, N.J.; LEWIS, F.; RANDALL, R. J. - Protein measurement with the folin phenol reagent. J. Biol. Chem., Baltimore, 193:265-75, 1951.

82. MAGALHÃES, M.; ANDRADE, M.; VERAS, A. - Uretrites não gonocócicas masculinas associadas a Chlamydia, Urea plasma e Trichomonas. Rev. Microbiol., São Paulo, 13 (2) $: 156-60,1982$.

83. MAGALHÃES, M. ; VEPAS, A.; ANDRADE, M. - Comparação entre "swabs" uretrais e seđimentos urinärios no $\underline{i}$ solamento de agentes causais de uretrites. Rev. Microbiol., São Paulo, 11(4):110-2, 1980

84. MAJORI, L.; CAMPELIO, C.; MANDRUZZATO, G.P.; SPANIO, P. - L'epideniologia delle micoplasmosi. Nota III. Mi coplasmosi genitale in gravidanza e transmissione neonataie. Boil. Ist. Sieroter Milan., 53(3): $515-$ $24,1.974$.

85. MZ.RTZINOVSKI, E.J.-De l'étiologie de la Péripneumonie. Ann. Inst. Pasteur., Paris, 25:914-7, 1911.

86. MATTHEWS, C.D.; EIMSIIE, R.G.; CLAPP, K.H.; SVIGOS, J.M. 
- The frequency of genital mycoplasma infection in humä fertility. Fertil. Steri.1. , Bimingham, 26 (10): $988-90,1975$.

87. MC COMARCK, W.M.; ROSNER, B.; LEE, Y.H.- Colonization with Genital Mycoplasma in women. Am.J.Epidemiol., Baltimore, $97(1): 240-5,1973$.

88. MC COMARCK, W.M.; ROSNER, B.; ALPERT, S.; EVRARD, J.R.; CROCKETT, V.A.; ZINNER, S.H. - Vaginal colanization with Mycoplasma hominis and Ureaplasma urealyticum. Sex. Trans. Di.s., Philadelp̣kia, 13 (2):67-70, 1986.

89. MC DONALD, M.I.; LAM, M.H.; BIRCH, D.F.; D'ARCY, A.F.; FAIRLEY, K.F.; PAVILLARD, E.R.J. - Ureaplasma urealyticum in patients with acute symptoms of uri nary tract infection. J. Urol., Baltimore, 128:5178,1982 .

90. MIETTINEN, A.; PAAVONEN, J.; JANSSON, E.; LEINIKKI, P. - Enzyme immunoassay for serum antibody to Muccpiasma hominis in women with acute pelvic inflammaiory disease. Sex. Trans. Dis., Philadelphia, 10:289-93, 1383.

91. MOURA, R.A.A.A.; PURCHIO, A.; ROSSI, A.L.R.; STRLFALDI, B.; NOGUEIRA, D.M. ; HOXTER, G.; COUTINHO. J.P.; AL MEIDA, T.V. - Técnicas de laboratório. 2.ed. São 
Paulo, Atheneu, 1982. p.230-3.

92. NOCARD \& ROUX. - Le microbe de la péripneumonie. zhnn. Inst. Pasteur.; Paris, 12:240-62; 1898 .

93. NOWAK, J. - Morphologie, nature et cycle evolutif du microbe de la pērìpneumonie des bovidé. Ann. Inst. Pasteur., Paris, 43:1330-52, 1929.

94. NOWAK, ت. \& LOMINSKI, I.- Morphologie et évolution du microbe de J.'agalaxie contagjeuse des ovins et des milieux nutitifs. Ann. Inst. Pasteur., Paris, 53: $438-51,1934$

95. OUCHTERLONY, O. - Antigen-antibody reation in gels. Acta. Pathol. Microbiol. Scand. Sect. B: Microbio., Copenhagen, 26:507-15, 1949 .

96. PERREAU, P.; GAYT, P.; MONNIER, J. -- Le méthode d'immunofluorescence et l'identification des Mycoplasmas. Application au diagnostic de la péripneumonia. Rev. Elev. Méd. Vét. Pays. Trop., Paris, 22 (4) : 481-93, 1969 .

97. PURCELL, R.H.; TAYLOR-ROBINSON, D.; WONG, D.C.; CHANOCK, R.M. A color test for the measurement of antibody to the non-acid-forming human mycoplasma species. Am. J. Epidemiol., Baltimore, 84:51-66, 1966. 
98. QUINN, P.A.; SHENCHUK, A.B.; SHJBER, J.; JIE, K.I.; RYAN, E.; SHEU, M.; CHIPMAN, M.I. - Serologic evidence cf Ureaplasma urearyticum tnfection in womein with spontaneous pregnancy loss. Am. J. Cbstet. Gynecol. , St.Louis, 145:245-9, 1983.

99, RAZIN, S. -- Characteristics of the Mycoplasmas as a group. In: RAZIN, S. \& TULLY, J.G., eds. Methods in mycoplasmology. New York, Academic Press, 1933, V.l. P. 3

100. RAZIN, S. - Mycoplasmas: the smallest pathogenic procaryotes. Isr. J. Med. Sci., Jerusalem, 17(7):510-5, 1981.

101. RAZIN, S. \& CIRILLO, V.P. - sugar fermentation. In: RAZIN, S. \& TULLY, J.G., eds. Methods in mycoplasmology. New York, Academic Press, 1983, v.1. p.337343 .

102. RAZIN, S. \& FREUNDT, E.A. - The mycoplasmas. In: BERGEYS manual of systematic Bacteriology. Baltimo ré, Williarss \& Wilkins, 1984. v.1. p.740-93.

103. RAZIN, S. \& TULLY, J.G. - Choiesterol reqidirement of Mycoplasmas. I. Bacteriol., Ealtimore, 102(2):306310,1970 .

104. REHEWY, M.S.I.; JASZCZAK, S.; HAFEZ, E.S.E.; THOMA.S, A.; BRCWN, W.J. -. Ureareasma urealyticum (T-m/coplasma) 
in vaginal fluid and cervical mucus from fertile and infertile woner. Fertil. Steril., birningham, $\underline{30}: 297-300 ; 1978$.

105. ROBINSON, M.I.; ALIISON, J.M.; HARTMAN, F.A.-Anaeroplasma abactoclasticum gen. nov., sp. nov. an obligately anaerobic mycoplasma from the rumen. Int. J.Syst. Bacteriol., Washington, 25(2):173-81, 1975.

106. ROMANO, N.; CAROLIO, F.; ROMANO, F. -- Mycoplasmas in aborted and malformed foetuses. Riv. Ist. Sieroter. Ital. , Napoles, $\underline{4} 3$ : 217-24, 1968.

107. ROTTEM, S.-Differentiation of sterol-requiring from sterol-nonrequiring mycoplasmas by amphotericin B. Appl. Microbiol., Washington, 23(3):559-60, 1972.

108. SABIN, A.B. - The filtrable microrganisms of the ple ropneumonia group. Bacteriol. Rev., Washington, $\underline{5}$ (1): 1-66, 1941 .

109. SAglio, P.; LHOSPttal, M.; LAFLEChE, D.; DUPONT, G; BOVE, J.M.; TULLY, J.G.; FREUNDT, E.A. - Spiroplasma citri gen. and sp. n.: a Mycoplasma-Like Organism asscciated with "stubborn" disease of Citrus. Int. J. Syst. Bacteriol., Washington, $23(\xi): 191-204,1973$.

110. SCFEFEFEL, A. - Asterococcus n.g. superbut (Cierik.) scherffel und dessen angebliche veziehungen zu 
eremosphaera. | Ber. Dtsch. Bot. Ges. A, Berlin, 22 : 762, 1908 Apud HAYELIC, L. હt àl. Dacteriol. ReV. 29. (2): 185-221, 1965 .

111. SHEPARD, M.C. - Cultivation and properties of T-strains of mycoplasma associated with nongonccoccal urethritis. Ann. N.Y. Acad. Scí., New York, 143:505-13, 1967.

112. SHEPARD, M.C. - The Recovery of Pleuropneumonia-Like Organisms from Negro Men with and without Nongonococcal Urethritis. Am. J. Syph. Gonorrea Vener. Dis., St.Louis, 38:11.3-24, 1954 .

113. SHEPARD, M.C. - Standard fluid medium 10 for cultivation and maintenance of lireaplasma urealyticum. Int. J. Syst. Bacteriol., Washington, 24:160-71, 1974.

114. SHEPARD, M.C. \& LUNCEFORD, C.D. - Differencial agar medium $\left(\mathrm{A}_{7}\right)$ for identification of Ureaplasina urealyticuni (Human T Mycoplasma) in primary cultures of clinical marerial. J. Clin. Microbiol., Washington, $\underline{3}(6)$ : $613-25,1976$.

115. SHEPARD, M.C.; LUNCEFORD, C.D.; FORD, D.K.; PURCELL, R.H.; TAYIOR-ROBINSON, D.; FAZIN, S.; BLACK, F.T. Ureaplasma urealyti.cum gen. nov., sp. nov.: Proposed Nomenclature for the Human T(T-strajn) Mycoplasmas. Int. J. Syst. Bacteriol., Nashington, 24(2):160-71, 1974 . 
116. SHEPARD, M.C. \& IUCEFORD, C.D. - Urease color test Mediurn U-y for the detection and idenlification of "T" mycoplasmas in clinical material. Appl. Microbiol。, washington, 20 (4):539-43, 1970.

117. SHOETENSACK, M. - Pure cultivation of the filtrable virus isolated from canine distemper. Kitasato Arch. Exp. Mec., Tokyo, 11:277-89, 1934.

118. SHURIN, P.A.; ALPERT, S.; ROSNER, B.; DRISCOLL, S.G.; LEE, Y,H.; MC CORMACK, W.M.; SANTAMARINA, B.A.G. ; KASS, E.H. - Chorioamnionitis and colonization fo the newborn infant with genital mycoplasmas. N. Engl. J. Med., Boston, 293:5-8, 1975

119. SKRIPAL, G.I. Revival of the Name Spiroplasmataceae fam. nov., nom.rev., omitted from the 1980 approved lists of bacterial names. Int. J. Syst. Bacteriol., Washington, $\underline{33}(2): 408,1983$.

120. SOMPOLINSKY, D.; SOLOMON, F.; LEIBA. H。; CASPI, E.; LEWINSOHN, G.; ALMOG, C. - Puerperal sepsis due to T-strain Mycoplusma. Isr. J. Med. Sci.., Jerusalēm, $7 \underline{7}: 745-8,1971$.

121. STRAY-PEDERSEN, B.; ENG, J.; REIKVIM, M.T.-Uterine T-mycoplasma colonization in reprosuctive failure. Am. J. Obstet. Gynecol., St.Louis, 130:307-11, 2978. 
122. STYLER, M. \& SHAPIRO, S.S. - "Mollicutes (mycoplasma) in infertility". Fertil. Steril, Birningbam, 44 (1):1-12, 1985.

123. Subcommittee on the Taxonomy of Mycoplasmatales. Recommendation on nomenclature of the order mycoplas matales. Science., Washington, 155:1694-6, 1967.

124. TAFARI, N.; ROSS, S.; NAEYE, R.L.; JUDGE, D.M.; MARBOE, C. - Mycoplasma T strains and perinatal death. Lancet, London, 17:108-9, 1986.

125. TANG, F.F. \& WEI, H. - An investigation of the causal agent of Bovine Pleuropneumonia. J. Pathol. Bacteriol. , Edinburgh, 40:391-406, 1935.

126. TAYLOR-ROBINSON, D.\& MC CORMACK, W.M. - The genital mycoplasmas. N. Engl. J. Med., Boston, 302:1063-7, 1980 .

127. TAYLOR-ROBINSON, D.; CSONKA, G.W.; PRENTICE, M.J. -Human Intra-uretral Inoculation of Ureaplasmas. J. Med. , Oxford, $\underline{46: 309-26,1977}$

128. THOMSEN, A.C. - Occurrence of mycoplasmas in urinary traciss of patients with acute pyelonephritis. J. Clin. Microbiol., Washington, $\underline{8}(1): 84-8,1978$.

129. TUILIY, J.G. \& SMITH, L.G. - Postpartum septicemia with 
Mycoplasma huminis. JIMA J. Am. ivea. Asscc., Chicego, $\underline{20} \underline{-1}(9) \cdot 109-70,1960$.

130. TURNER, A.W. - A study of the morphology and life cycles of the organism of Pleuropneumonia Contagiosa Boum (Borrelomyces peripneumoniae nov.gen.) J. Pathol. Bacteriol., Edinburgh, $41: 1-32,1930$

131. VELIECA, W.M.; BIRD, B.R.; FORRESTER, F.T. - Arginine broth medium for grouth of M.hominis. In: LABORATORY diagnosis of mycoplasma infections: U.S.Dep. of Health, Education, and Felfare, CDC., Atlanta, 1979. p.120.

132. VINTHER, O.--Biochemistry of Mycoplasma hominis. Sex. Trans. Dis. , Philadelphia, 10 (4suppl..) :244-6, 1983.

133. WEIDNER, W.; BRUNNER, H.; KRAUSE, W. - Quantitative culture of Ureaplasma urealyticum in patients with chronic prostatitis or porstatosis. I. Urol., Baltimose, 124:622-5, 1980 .

134. WROBLEWSKI, W. - Morphologie et cycle evolutif des microbes de la péripneuncnie des bovides et cie l'agalaxie contagieuse des chēvres et des moutons. Ann. Inst. Pasteur., Paris, 47 $194-115,1.931$. 